\title{
PINYON PINE MORTALITY ALTERS COMMUNITIES OF GROUND-DWELLING ARTHROPODS
}

\author{
Robert J. Delph1,2,6, Michael J. Clifford ${ }^{2,3}$, Neil S. Cobb ${ }^{2}$, Paulette L. Ford ${ }^{4}$, and Sandra L. Brantley ${ }^{5}$
}

\begin{abstract}
Aвstract-We documented the effect of drought-induced mortality of pinyon pine (Pinus edulis Engelm.) on communities of ground-dwelling arthropods. Tree mortality alters microhabitats utilized by ground-dwelling arthropods by increasing solar radiation, dead woody debris, and understory vegetation. Our major objectives were to determine (1) whether there were changes in community composition, species richness, and abundance of ground-dwelling arthropods associated with pinyon mortality and (2) whether specific habitat characteristics and microhabitats accounted for these changes. We predicted shifts in community composition and increases in arthropod diversity and abundance due to the presumed increased complexity of microhabitats from both standing dead and fallen dead trees. We found significant differences in arthropod community composition between high and low pinyon mortality environments, despite no differences in arthropod abundance or richness. Overall, $22 \%$ (51 taxa) of the arthropod community were identified as being indicators of either high or low mortality. Our study corroborates other research indicating that arthropods are responsive to even moderate disturbance events leading to changes in the environment. These arthropod responses can be explained in part due to the increase in woody debris and reduced canopy cover created by tree mortality.
\end{abstract}

Resumen.-Documentamos el efecto de la mortalidad causada por la sequía del pino piñonero (Pinus edulis Engelm.) sobre comunidades de artrópodos subterráneos. Utilizamos tres variantes en el microhábitat de los artrópodos incrementando la radiación solar, desechos de madera muerta y vegetación baja. Nuestros objetivos principales fueron: (1) determinar si se producían cambios asociados con la mortalidad del pino en la composición de la comunidad, la riqueza de especies y la abundancia de artrópodos y (2) saber si algunas características específicas del hábitat y microhábitat tenían algo que ver con estas diferencias. Nuestra predicción fue que encontraríamos cambios en la composición de la comunidad y un aumento de la diversidad y la abundancia de artrópodos debido al esperado aumento de complejidad de los micro-hábitats dada por los árboles muertos en pie y los caídos. Encontramos diferencias significativas en la composición de la comunidad de artrópodos entre la alta y baja mortalidad de los pinos a pesar de que no encontramos diferencias ni en la abundancia ni en la riqueza. En general, el 22\% (51 taxa) de la comunidad de artrópodos fueron identificados como indicadores de ambas, alta o baja mortalidad. Nuestro estudio apoya otra investigación que indica que los artrópodos son sensibles a disturbios moderados que resultan en cambios en el medio ambiente y éstos se pueden explicar, en parte, por el aumento de deshechos de madera y a la reducción de la cubierta fina de follaje creada por los árboles muertos.

Arthropod communities can be highly responsive to temporal and spatial environmental changes over the landscape, including climate (Larocque et al. 2001), habitat alteration (Intachat et al. 1997, Ellis et al. 2001), topography, soil type, fire, and plant quality (Parmenter et al. 1989). Small size, rapid population growth, short life cycle, and high mobility make arthropods useful in detecting fine-scale spatial variation and short temporal changes. In assessing habitat quality, arthropod species often serve as indicators of both undisturbed (Morrison and Marcot 1995) and disturbed ecosystems (González-Megías et al. 2004).
Pinyon-juniper woodlands are one of the most extensive vegetation types in western North America and cover approximately 19 million ha (Evans 1988). Pinyon pine exists as a codominant with one-seeded juniper (Juniperus monosperma [Engelm.] Sarg.) throughout New Mexico. Within our study region, pinyons comprise $55 \%$ of woodland canopy cover and are a major food and habitat source for many vertebrate and invertebrate species; a decrease of this vegetation type could have dramatic consequences on species occurring in pinyon-juniper woodlands (Brown et al. 2001). Since 1996, many areas of the southwestern

\footnotetext{
${ }^{1}$ Select Engineering Services, Department of Natural Resources, Dugway Proving Ground, Dugway, UT 84022

${ }^{2}$ Merriam-Powell Center for Environmental Research and Colorado Plateau Museum of Arthropod Biodiversity, Northern Arizona University, Flagstaff, AZ 86011.

${ }^{3}$ Earth and Environmental Science Department, Lehigh University, Bethlehem, PA 18015.

${ }^{4}$ USDA Forest Service, Rocky Mountain Research Station, Albuquerque, NM 87102.

5 Museum of Southwestern Biology, University of New Mexico, Albuquerque, NM 87131.

${ }^{6} \mathrm{E}$-mail: robert.delph@nau.edu
} 
United States have experienced drought conditions. The drought that occurred in 2002 was considered the worst drought in the western United States in 500 years (USGS 2004). Droughts can lead to increased frequency of insect herbivore pest outbreaks (Logan et al. 2003, Breshears et al. 2005). Aerial surveys and ground studies in pinyon-juniper woodlands throughout the Southwest have shown regional mortality of pinyons as a result of bark beetle outbreaks (Breshears et al. 2005, Shaw et al. 2005, Kleinman et al. 2012). Pinyon pine mortality was extensive throughout the Middle Rio Grande Basin, averaging $65 \%$, whereas juniper mortality was only $3 \%$ (Floyd et al. 2009). Several studies show the impacts of tree stress on insect herbivores directly associated with pinyons (Cobb et al. 1997, Trotter et al. 2008), but little work has been done on the community of grounddwelling arthropods indirectly associated with pinyons.

We predicted that tree die-off would alter abundance, species richness, and community composition of ground-dwelling arthropods due to the conversion of live tree crowns to dead ones and the increase in complexity of microhabitats from fallen woody debris. Our major objectives were to (1) determine differences in species composition, relative abundances, and species richness of ground-dwelling arthropods associated with environments experiencing high pinyon mortality and environments experiencing low pinyon mortality and (2) correlate habitat variables that distinguish high- and low-mortality habitats within the pinyon-juniper woodland that could account for differences in arthropod communities.

\section{Methods}

\section{Study Area and Design}

To examine the regional response of grounddwelling arthropods to pinyon mortality, we selected 6 sites among the pinyon-juniper woodlands of the Middle Rio Grande Basin (MRGB) of New Mexico (Fig. 1). The documented mortality levels of pinyon differed throughout the MRGB (Clifford et al. 2013); therefore, we selected sites on the basis of relative mortality. Each of 3 regions in the MRGB study area (north, central, and south) included a high-mortality site paired with a low-mortality site. Within each region, the low-mortality site was located within $10 \mathrm{~km}$ of the high-mortality site and was the lowest mortality location that we could find and logistically sample (Table 1). The distances between regions were $32.1 \mathrm{~km}$ between north and central and $80.4 \mathrm{~km}$ between central and south. At each of the 6 sites, we established thirty-two $100-\mathrm{m}^{2}$ plots with one pitfall trap placed at the center of each plot. We used 16 of these plots to correlate arthropod community characteristics with stand structure, ground cover, and dead and down woody debris.

\section{Documenting Drought and Ensuing Normal Climate}

Although the drought and tree mortality event has been extensively documented (e.g., Breshears et al. 2005, Floyd et al. 2009), we assessed whether the study area experienced both drought conditions and normal conditions by applying interpolated PRISM data (Daly 2002) to the study area. We confirmed that precipitation levels in the MRGB significantly $(P<0.001)$ decreased $34 \%$ in 2002-2003 from predrought (1976-2001) conditions, and then returned to historical levels prior to and during this study (2004-2007; USGS 2004; Appendix 1). This confirmation process was important because we wanted to test the indirect effects of drought on arthropods through habitat alteration, without the complication of the direct effect of drought on arthropods.

\section{Stand Structure}

We measured stand structure at 16 of the 32 plots within a site. Measurements records included the tree species (Pinus edulis, Pinus ponderosa, or Juniperus monosperma), the tree's status (e.g., alive or dead), and the crown area. Pinyon and juniper crown structure approximates a cube, and crown area was calculated by measuring 2 diameters of the crown with a meter pole-each measurement perpendicular to the other-and then multiplying the diameters to obtain area. The endpoints for tree diameters and tree height were not the tips of the crown but a visual average of the tips for the side of the tree being measured so as to fill a cube. Canopy area was then summed in each subplot to calculate canopy area of each overstory tree species and overall canopy area. 


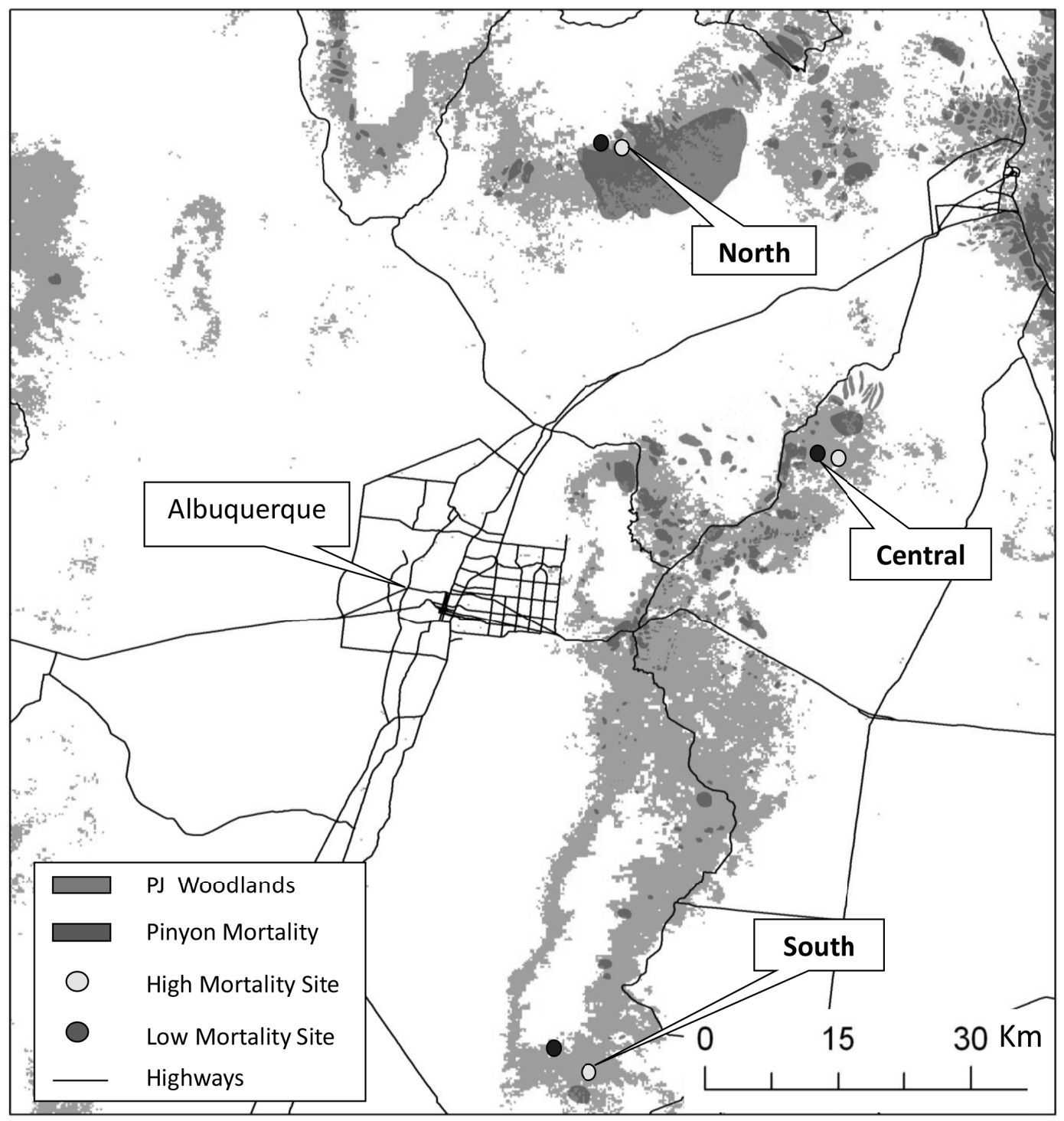

Fig. 1. Map of the Middle Rio Grande Basin (MRGB) study area showing the 3 sets of paired study sites (circles). Areas of high pinyon mortality were identified by the USDA Forest Service, Forest Enterprise Team. We selected 6 paired low- and high-mortality study sites located in the north (Jemez Mountains, Sandoval Co.), central (San Pedro Mountains, Santa Fe Co.), and south (Manzano Mountains, Torrance Co.) portions of the MRGB of New Mexico (see Table 1 for site coordinates). The distance between regions was $32.1 \mathrm{~km}$ between north and central and $80.4 \mathrm{~km}$ between central and south.

TABLE 1. Locations of the paired low and high pinyon mortality sites in the Middle Rio Grande Basin study area, New Mexico (datum WGS 84).

\begin{tabular}{lcccl}
\hline Region & Pinyon mortality & Latitude & Longitude & Descriptor \\
\hline \multirow{2}{*}{ Northern } & Low & $35.674^{\circ}$ & $-106.494^{\circ}$ & Jemez Mtns., Sandoval Co. \\
\multirow{2}{*}{ Central } & High & $35.676^{\circ}$ & $-106.461^{\circ}$ & \\
& Low & $35.309^{\circ}$ & $-106.161^{\circ}$ & San Pedro Mtns., Santa Fe Co. \\
\multirow{2}{*}{ Southern } & High & $35.311^{\circ}$ & $-106.124^{\circ}$ & \\
& Low & $34.556^{\circ}$ & $-106.439^{\circ}$ & Manzano Mts., Torrance Co. \\
& High & $34.545^{\circ}$ & $-106.351^{\circ}$ & \\
\hline
\end{tabular}




\section{Ground Cover and Woody Debris as Measures of Habitat Complexity}

We measured 5 classes of ground covershrubs, grasses, forbs, litter, and bare ground —in all 32 plots at each site. Each $100-\mathrm{m}^{2}$ plot was divided into four $25-\mathrm{m}^{2}$ sections. A $1-\mathrm{m}^{2}$ quadrat frame was randomly placed in 3 of these sections. Ground cover was estimated in each quadrat by measuring the amount of area taken up by shrubs, grasses, forbs, litter, rock, soil, and other elements such as dead wood, moss, and dung. The $1-\mathrm{m}^{2}$ measurements were extrapolated to estimate total cover in each 100- $\mathrm{m}^{2}$ plot (ITT 1996).

We estimated fallen woody debris using the plane-intercept method (Kershaw 1973, Brown 1974, Grieg-Smith 1983). Within each 100-m² plot, a $10-\mathrm{m}$ line was placed in a north to south direction. We recorded abundance and volume of dead, fallen branches, twigs, and logs. Percent decay was estimated by the degree of breakability (Brown 1974) and the amount of bark still on the branch or twig. In addition, 2 litter-depth measurements were also taken $2 \mathrm{~m}$ north and $2 \mathrm{~m}$ south from the center of the 10-m line to obtain an estimate of organic matter added to the surface. A modified Brown (1974) fuel loads classification by diameter $(\mathrm{cm})$ of woody debris was used. Each piece of woody debris measured was placed in a classification based on diameter $(\mathrm{cm})$ of the woody debris (A, <0.64 cm; B, 0.64-2.54 cm; C, $2.54-7.62 \mathrm{~cm}$; and D, >7.62 cm).

\section{Sampling of Ground-dwelling Arthropods}

Within each site we deployed 32 pitfall traps-one trap in each plot. A pitfall trap consisted of a glass test tube $(2.5 \mathrm{~cm}$ diameter $\times 15 \mathrm{~cm}$ length) encased in PVC pipe, complete with a PVC cover to keep rain and debris from falling into the trap. Each test tube was filled with a 1:1 dilution of water and propylene glycol (e.g., Dennis et al. 1997). Arthropods were sampled each summer (14 July-3 August) for 3 years (2005-2007). For each sampling period, the traps were left open for a period of 21 days, and then collected. After the traps were collected, all specimens were removed from the propylene glycol and stored in $70 \%$ ethanol. Based on a literature review, we included all arthropods that we presumed to spend a significant amount of their life history on or near the ground, and we refer to this group as the "surface-dwelling" community (e.g., Lightfoot et al. 2008, Higgins et al. 2014). Specimens were identified to the species level or as morphospecies. A permanent reference collection is curated by the Colorado Plateau Museum of Arthropod Biodiversity at Northern Arizona University.

Since high-mortality sites experienced the greatest amount of habitat change, an additional 120 pitfall traps were placed in specific microhabitats to measure microhabitat specificity among arthropod species. We placed pitfall traps in 4 different microhabitats nearby and adjacent to each of the high-mortality sites. A single pitfall trap was placed under each of 30 dead pinyons, 30 live pinyons, 30 live junipers, and 30 open areas, for a total of 120 traps outside of, but adjacent to, the plot perimeter at each of the 3 high-mortality sites. Traps under trees were placed midway between the tree trunk and the edge of the crown; traps in the open were at least $2 \mathrm{~m}$ from a tree crown. Individual microhabitat traps were far enough apart from each other so that the tree crown of one tree would not influence the other. If differences in arthropod communities were present between high- and low-mortality sites, we would expect differences in specific microhabitats within environments experiencing large pinyon pine dieoff. Arthropods were sampled and processed in the same manner as for the 32 uniform plots in high- and low-mortality sites, except that we only sampled microhabitat in 2005 (16 July-5 August). We measured tree crown area and litter depth as for the uniform plots. All trees selected were of comparable heights and widths.

\section{Statistical Analyses}

One-way ANOVA univariate analysis was used to compare means of tree density, canopy area, and percent vegetation cover and vegetation abundance between high- and low-mortality environments. Measurements of downed woody debris were sorted into fuel burn time classifications and used to estimate total volume of each measurement. Means of volumes for each fuels load classification were compared between high- and low-mortality areas using a one-way univariate ANOVA. We performed both parametric and nonparametric analyses to assess the arthropod communities and habitat characteristics for the high- and lowmortality comparisons. A one-way univariate 
ANOVA (Levene's test of equality error variances) and repeated measures ANOVA were used to compare means of habitat variables, arthropod abundance, and arthropod species richness between sites with high and low pinyon mortality. The repeated measures analysis allowed us to consider the differences between arthropod communities without biasing data on time periods or sampling location. In addition we compared the means of specific feeding guilds and major arthropod groups within each site to determine if there were specific groups that showed significant differences between specific microhabitats and mortality sites. All analyses were performed in SPSS (version 16.0; SPSS 2007) and significant values were accepted at the 0.05 probability level.

PCORD (Clarke and Gorley 2006) was used to run species indicator analyses and species accumulation curves, and Primer (McCune and Mefford 2006) was used to run community analyses for arthropods collected in high and low pinyon mortality sites for each area and each year. Species accumulation analysis using the UGE curve (Ugland et al. 2003) was used to determine the efficacy of pitfall traps in sampling the surface-dwelling community at each site in each year. We used a multiresponse permutation procedure (MRPP) as a quantitative measure to explain arthropod community difference between mortality sites. A nonmetric multidimensional scaling (NMS) scatter plot (Clarke 1993) was used as a descriptive method to examine similarities of arthropod species assemblages between mortality sites and habitat types, based on BrayCurtis distance (Beals 1984, McCune and Beals 1993). Species indicator analysis using a Monte Carlo test of significance determined whether specific arthropod taxa were found in certain habitat types or associated with certain habitat characteristics (McCune and Grace 2002). A standard linear least-squares regression analysis was then used to determine which indicator taxa were correlated with certain habitat characteristics that characterize mortality habitats.

\section{RESUlTS}

\section{Stand Structure}

Pinyon mortality, in terms of percentage of trees, was significantly higher in the high- mortality sites at all 3 regions $(n=16, P<$ $0.001)$. The north and central regions had $>20 \%$ pinyon mortality in the high-mortality sites, whereas the southern region had the least amount of pinyon mortality with $8 \%$. Additionally, there were no significant differences in total tree density between high and low pinyon mortality sites $(n=16, P=0.433)$. However, pinyon canopy cover was significantly higher in the low pinyon mortality sites $(n=16, P<0.001)$, and overall pinyon canopy loss was significantly higher in the high-mortality sites $(n=16, P=0.009$; Fig. 2a). Juniper canopy cover showed no significant differences $(n=16, P=0.200)$ and little to no canopy loss between pinyon mortality levels (Fig. 2b), whereas ponderosa canopy cover was significantly higher in the low pinyon mortality sites for the north and central regions $(n=16, P=0.043$; Fig. $2 \mathrm{c})$. However, canopy cover for all tree species combined was significantly higher in the low pinyon mortality sites for each of the 3 study regions $(n=16, P<0.001)$ and was driven mostly by pinyons (Fig. 2d).

\section{Ground Cover Differences and Woody Debris}

Grasses were the primary herbaceous cover for all sites (Table 2). Percent ground cover of grasses was significantly higher in the highmortality sites $(n=32, P=0.007)$, which shows a positive relationship with pinyon mortality. Blue grama (Bouteloua gracilis [Willd. ex Kunth] Lag. ex Griffiths) was the most common grass species. This species was significantly more abundant in the high-mortality sites $(n=32, P=0.040)$ and was found in all 3 regions. Western wheatgrass (Pascopyrum smithii [Rydb.] A. Löve) was significantly more abundant in the low-mortality environments ( $n=32, P=0.005)$. However, this species only occurred in the central and north regions and was very scarce in the high-mortality sites.

Total volume of woody debris was significantly ( $n=32, P=0.003$ ) higher in the highmortality sites. This relationship was driven by woody debris $>2.54 \mathrm{~cm}$ diameter (Table 2), which constituted the majority of the woody debris. Woody debris $>2.54 \mathrm{~cm}$ diameter averaged $4.9 \mathrm{~cm}$ diameter and was significantly more abundant in the high-mortality sites $(n=32 ; 2.54-7.62 \mathrm{~cm}, P<0.001 ;>7.62$, $P=0.010)$, thus increasing the overall volume of woody debris. Volume of smaller woody 
a

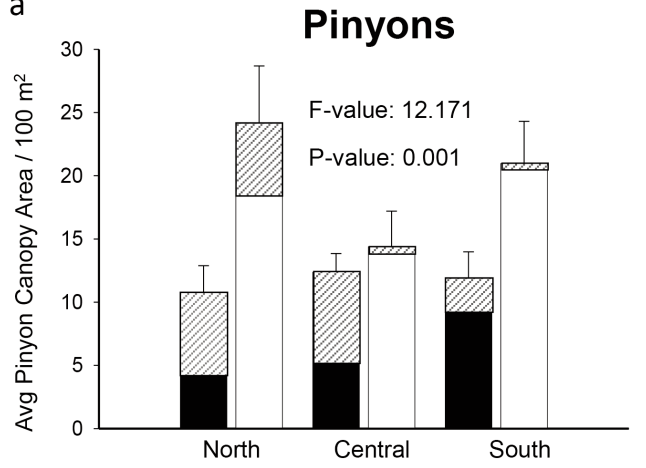

C

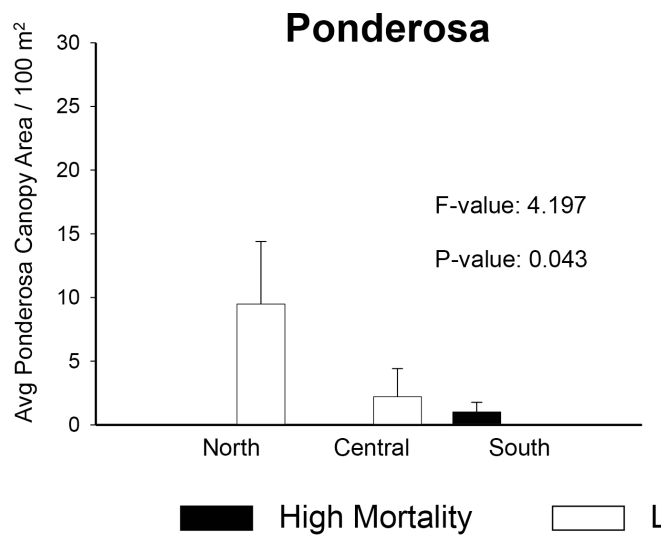

b

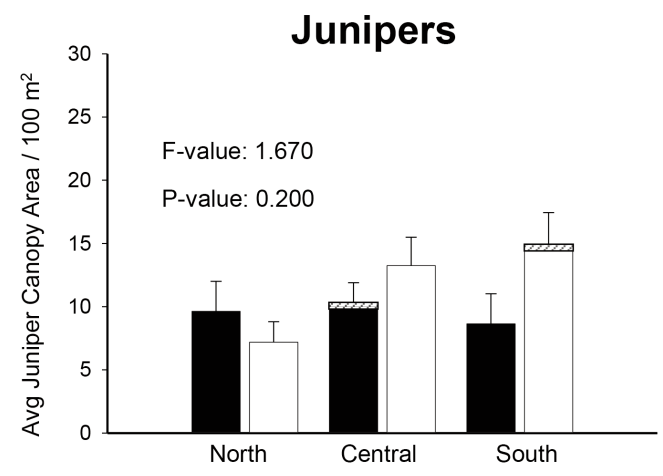

d Total Canopy Cover

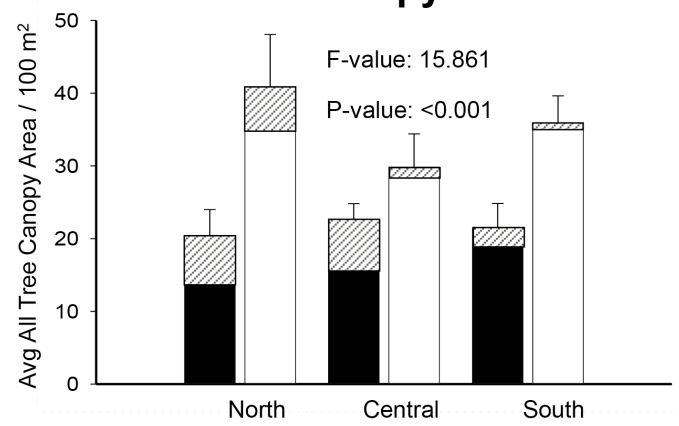

Low Mortality $\quad \mathscr{\mathbb { U }}$ Canopy Loss

Fig. 2. Mean canopy area $\left(\mathrm{m}^{2}\right)$ at each site (bars) for each tree type: a, pinyon pine; $\mathbf{b}$, juniper; $\mathbf{c}$, ponderosa pine; $\mathbf{d}$, all trees combined.

debris $(<0.64 \mathrm{~cm}$ to $2.54 \mathrm{~cm}$ diameter $)$ was not significantly different between high- and low-mortality sites.

Responses of Ground-dwelling Arthropods to High Pinyon Mortality Habitats

Species accumulation analysis indicated that 32 pitfall traps were more than sufficient to obtain a satisfactory representation of the community of surface-dwelling arthropods (Appendix 2). A total of 564 taxa (38,871 individuals) were collected from pitfall traps, and more than $80 \%$ of the taxa were identified to species or morphospecies level. Of the 564 taxa collected, we used 225 taxa $(36,627$ individuals) in our analysis and operationally defined the set as our surface-dwelling community (Appendix 3). We found no significant differences in arthropod abundance between low- and high-mortality sites from 2005 to $2006(n=32, P=0.398)$. However, there were significantly more arthropods in the high-mor- tality sites in 2007 for all 3 regions $(n=32, P$ $=0.052$ ). Arthropod abundance was variable between sites and years in 2005-2006 but showed a consistent pattern in all 3 regions in 2007. Species richness was not significantly different between high- and low-mortality sites in 2005 and $2007(n=32, P=0.702)$ but was significantly higher in the low-mortality sites in $2006(n=32, P=0.018$; Table 3). Despite the significance in 2006, species richness was variable between sites and between years, showing no consistent trend. In 2006, species richness was higher in the low-mortality sites but only for the north and south regions.

Arthropod feeding guilds of predators and omnivores/detritivores showed no consistent patterns between high- and low-mortality sites. Herbivores were significantly more abundant in high-mortality sites for all years $(n=32, P<$ 0.001 ) except 2005. In 2005, herbivore abundance was higher in all high-mortality sites but not at a significant level $(n=32, P=0.063)$. 
TABLE 2. Habitat attributes that characterize high and low pinyon mortality sites. Results of ANOVA tests are given as $P$ values

\begin{tabular}{|c|c|c|c|c|c|}
\hline & \multicolumn{2}{|c|}{ High mortality } & \multicolumn{2}{|c|}{ Low mortality } & \multirow[b]{2}{*}{$P$ value } \\
\hline & Mean & $\mathrm{SE}$ & Mean & $\mathrm{SE}$ & \\
\hline \multicolumn{6}{|l|}{ Ground cover type } \\
\hline Shrub cover $(\%)$ & 7.45 & 0.92 & 8.31 & 1.04 & 0.0805 \\
\hline Grass cover $(\%)$ & 12.08 & 1.04 & 8.89 & 0.80 & 0.0065 \\
\hline Forb cover $(\%)$ & 11.63 & 0.89 & 10.26 & 0.85 & 0.3299 \\
\hline Litter cover $(\%)$ & 32.26 & 2.22 & 34.57 & 2.03 & 0.7917 \\
\hline Bare ground cover $(\%)$ & 32.04 & 1.93 & 30.71 & 1.72 & 0.5698 \\
\hline \multicolumn{6}{|l|}{ Woody debris size class ${ }^{\mathrm{a}}$} \\
\hline All size classes & 49498.10 & 15766.72 & 11424.18 & 4668.79 & 0.0031 \\
\hline$<0.64 \mathrm{~cm}$ diameter & 13.17 & 4.03 & 13.53 & 4.83 & 0.9230 \\
\hline $0.64-2.54 \mathrm{~cm}$ diameter & 951.98 & 185.44 & 781.73 & 235.45 & 0.3588 \\
\hline $2.54-7.62 \mathrm{~cm}$ diameter & 9167.46 & 2273.55 & 3642.35 & 1140.70 & 0.0004 \\
\hline$>7.62 \mathrm{~cm}$ diameter & 39365.50 & 15133.67 & 6986.57 & 4338.23 & 0.0102 \\
\hline
\end{tabular}

TABLE 3. Arthropod species richness and abundance between high and low pinyon mortality sites from 2005 to 2007 . Results of ANOVA tests are given as $P$ values.

\begin{tabular}{|c|c|c|c|c|c|}
\hline & \multicolumn{2}{|c|}{ High mortality } & \multicolumn{2}{|c|}{ Low mortality } & \multirow[b]{2}{*}{$P$ value } \\
\hline & Mean & $\mathrm{SE}$ & Mean & $\mathrm{SE}$ & \\
\hline \multicolumn{6}{|c|}{ Species richness } \\
\hline All years & 37.9 & 1.4 & 38.3 & 1.2 & 0.7027 \\
\hline 2005 & 39.4 & 2.2 & 38.9 & 2.2 & 0.7821 \\
\hline 2006 & 30.4 & 2.2 & 34.3 & 1.8 & 0.0182 \\
\hline 2007 & 44.1 & 1.9 & 41.7 & 2.0 & 0.1490 \\
\hline \multicolumn{6}{|c|}{ Total abundance } \\
\hline All years & 209.3 & 32.9 & 183.4 & 29.5 & 0.3989 \\
\hline 2005 & 198.5 & 48.3 & 194.7 & 63.8 & 0.9505 \\
\hline 2006 & 149.2 & 36.1 & 179.3 & 53.4 & 0.5027 \\
\hline 2007 & 279.6 & 76.4 & 178.4 & 19.1 & 0.0528 \\
\hline
\end{tabular}

TABLE 4. Abundance of arthropod feeding guilds and major taxonomic groups between high and low pinyon mortality sites. Results of ANOVA tests are given as $P$ values.

\begin{tabular}{|c|c|c|c|c|c|}
\hline & \multicolumn{2}{|c|}{ High mortality } & \multicolumn{2}{|c|}{ Low mortality } & \multirow[b]{2}{*}{$P$ value } \\
\hline & Mean & $\mathrm{SE}$ & Mean & $\mathrm{SE}$ & \\
\hline \multicolumn{6}{|l|}{ Feeding guild } \\
\hline Predators & 24.3 & 5.9 & 31.28 & 4.64 & 0.2015 \\
\hline Herbivores & 53.53 & 16.03 & 11.57 & 1.42 & 0.0003 \\
\hline Omnivores/detritivores & 130.41 & 18.67 & 140.13 & 28.33 & 0.6941 \\
\hline \multicolumn{6}{|l|}{ Major taxonomic group } \\
\hline Acrididae & 7.77 & 1.16 & 9.62 & 1.07 & 0.0754 \\
\hline Tenebrionidae & 3.13 & 0.47 & 2.27 & 0.41 & 0.0286 \\
\hline Carabidae & 2.56 & 0.59 & 0.75 & 0.23 & 0.0004 \\
\hline Ants & 138.09 & 30.81 & 104.35 & 25.19 & 0.2475 \\
\hline Arachnids & 13.1 & 1.62 & 25.47 & 3.4 & 0 \\
\hline
\end{tabular}

Some common taxa among ground-dwelling arthropods showed consistent differences between high- and low-mortality sites. Darkling beetles (Tenebrionidae) and ants (Formicidae) were the most abundant omnivore/detritivores, but only darkling beetles were significantly more abundant in the high-mortality sites in 2007 ( $n=32, P=0.027)$. Predaceous ground beetles (Carabidae) were also significantly more abundant in the high-mortality sites in 2007 ( $n$ $=32, P<0.001)$. Arachnids were the most abundant predators and were significantly 


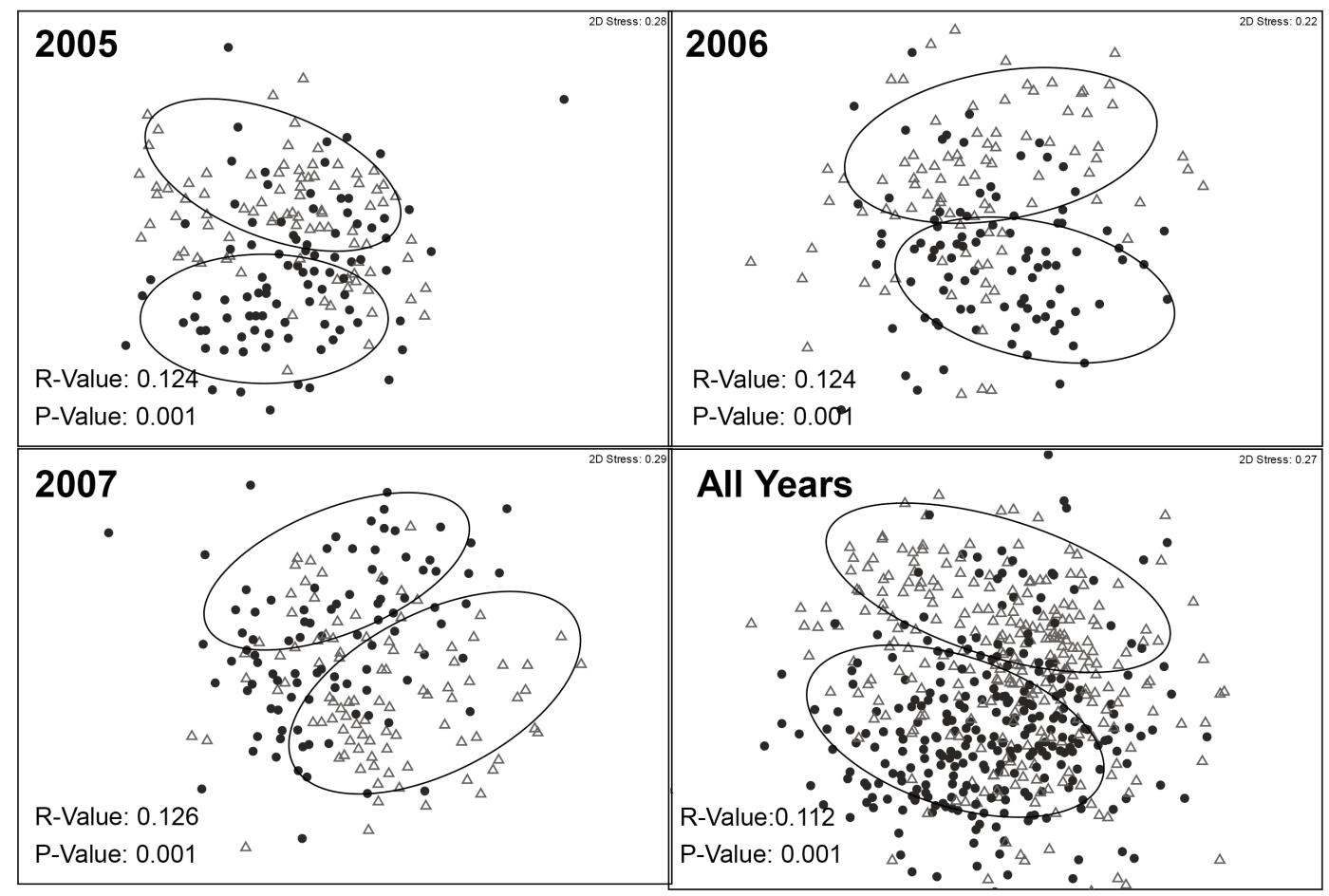

$\triangle$ High Pinyon Mortality

Low Pinyon Mortality

Fig. 3. Scatter plot showing arthropod community differences between high and low pinyon mortality sites from 2005 to 2007. Open triangles represent the arthropod community from high-mortality sites, and solid circles indicate the arthropod community from low-mortality sites. The large circles around the clustered groups are only to aid the reader's eye; they encircle the groupings and are not meant to suggest causality. Results from MRPP are given as R and $P$ values.

more abundant in the low-mortality sites for all 3 years and all 3 sites $(n=32, P<0.001$; Table 4). Mites in the family Erythraeidae were the major contributors to arachnid abundance $(n=32, P<0.001)$.

Community analysis of ground-dwelling arthropods showed community composition to be significantly different between high- and lowmortality sites from 2005 to 2007 , for all sites combined $(\mathrm{R}=0.112, P<0.001$; Fig. 3$)$. Analysis of each site independently showed a consistent trend in community composition of ground-dwelling arthropods to be fundamentally different between the high- and low-mortality sites for all 3 regions (Fig. 4). Although the high-mortality site in the southern region exhibited substantially less tree mortality than either the central or northern high-mortality sites, the difference in arthropod community composition was still statistically significant.

\section{Arthropod Responses to Microhabitats}

Within high-mortality sites, our analysis of 4 microhabitats (live pinyon, dead pinyon, live juniper, and open areas) showed grounddwelling arthropods to be significantly more abundant under live pinyons than in any other microhabitat type and least abundant in open areas $(n=120, P<0.001)$. Open areas also had a community composition significantly different from the other 3 microhabitats $(\mathrm{R}=$ $0.177, P<0.001)$. Community differences between live pinyon and dead pinyon microhabitats were significant when all sites were grouped together $(\mathrm{R}=0.004, P=0.027)$ but not within each site independently. All open area communities differed strongly from the forested sites (Fig. 5). Arthropod communities under live junipers showed similarities in composition to those under live pinyons. 


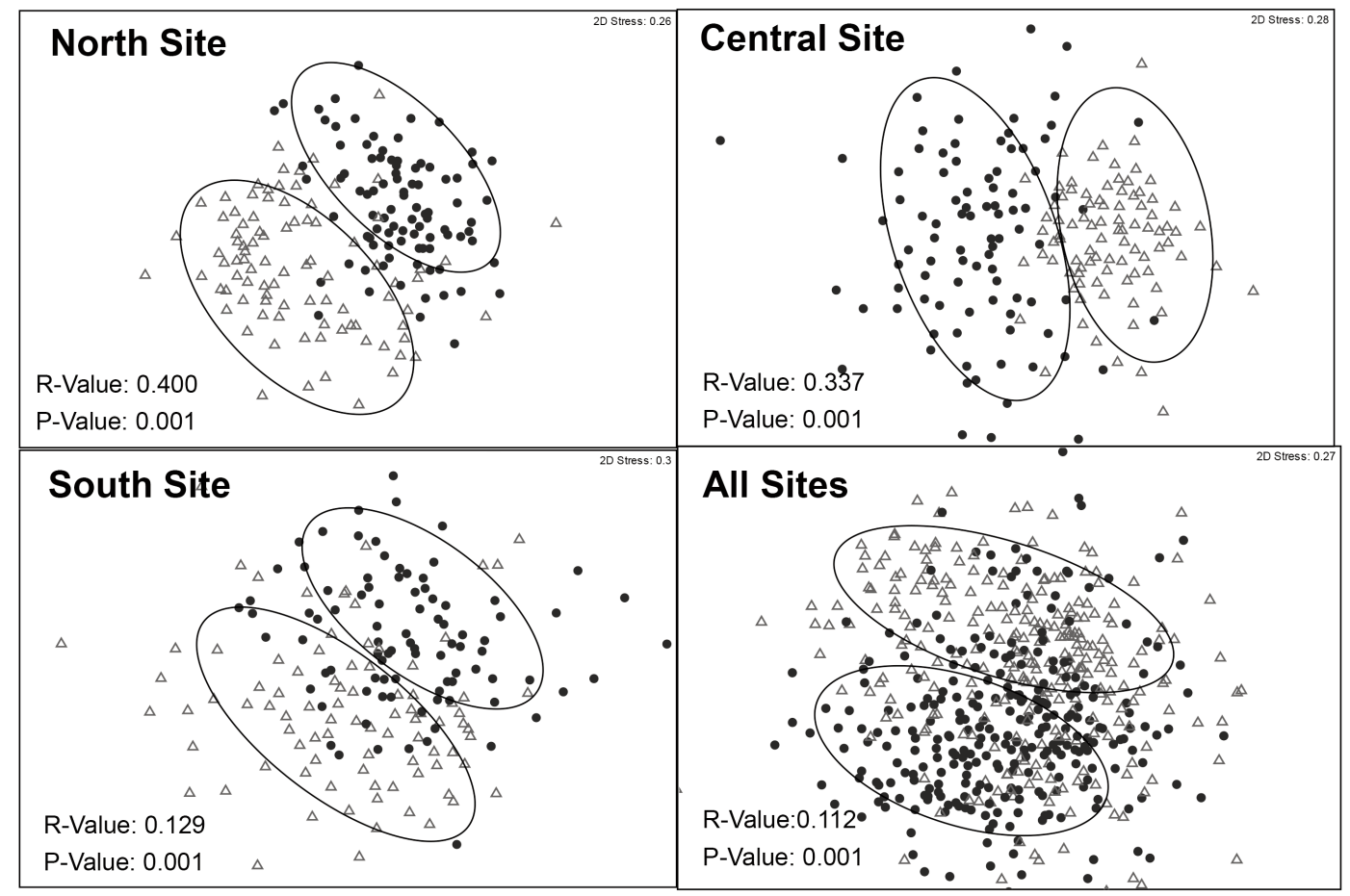

High Pinyon Mortality

Low Pinyon Mortality

Fig. 4. Scatter plot showing arthropod community differences between mortality sites in each region. Open triangles represent the arthropod community from high-mortality sites and solid circles indicate the arthropod community from low-mortality sites. The large circles around the clustered groups are only to aid the reader's eye; they encircle the groupings and are not meant to suggest causality. Results from MRPP are given as R and $P$ values.

\section{Arthropod Indicators}

Of the 225 surface-dwelling taxa, $22 \%$ (51 species) were indicators of either high or low pinyon mortality habitats: 28 species for highmortality sites and 23 for low-mortality sites. We operationally defined strong arthropod indicator species as taxa that were both frequent and abundant in a site, as well as having a strong correlation with specific habitat attributes that characterize high or low pinyon mortality sites. A regression analysis of all mortality indicator species on specific habitat attributes that characterize high- or low-mortality habitats showed only 6\% (14 species) of them to be strong indicators of pinyon mortality ( $3 \%$ high and 3\% low) (Table 5).

In the microhabitat plots, $49 \%$ (51 species) of the 104 surface-dwelling taxa were indicators of specific microhabitats (5 of dead pinyon, 11 of live pinyon, 5 of live juniper, and
30 of open areas), and 20\% (21 species) were also indicators of high or low pinyon mortality. We combined dead pinyon microhabitat and open areas as characteristic of high pinyon mortality, whereas we considered live pinyon microhabitat characteristic of low pinyon mortality. Live juniper microhabitat was found in equal abundance in both high- and low-mortality sites. We selected 30 of the arthropod taxa that had the highest microhabitat indicator values and found that 16 were also mortality indicators (9 high-mortality and 7 low-mortality). Of those 16 mortality indicators, 14 were correlated with a habitat type that is characteristic of either high or low pinyon mortality. At least 10 of the microhabitat indicators were defined as strong mortality indicators that were correlated with a habitat attribute that characterizes high or low pinyon mortality sites. 


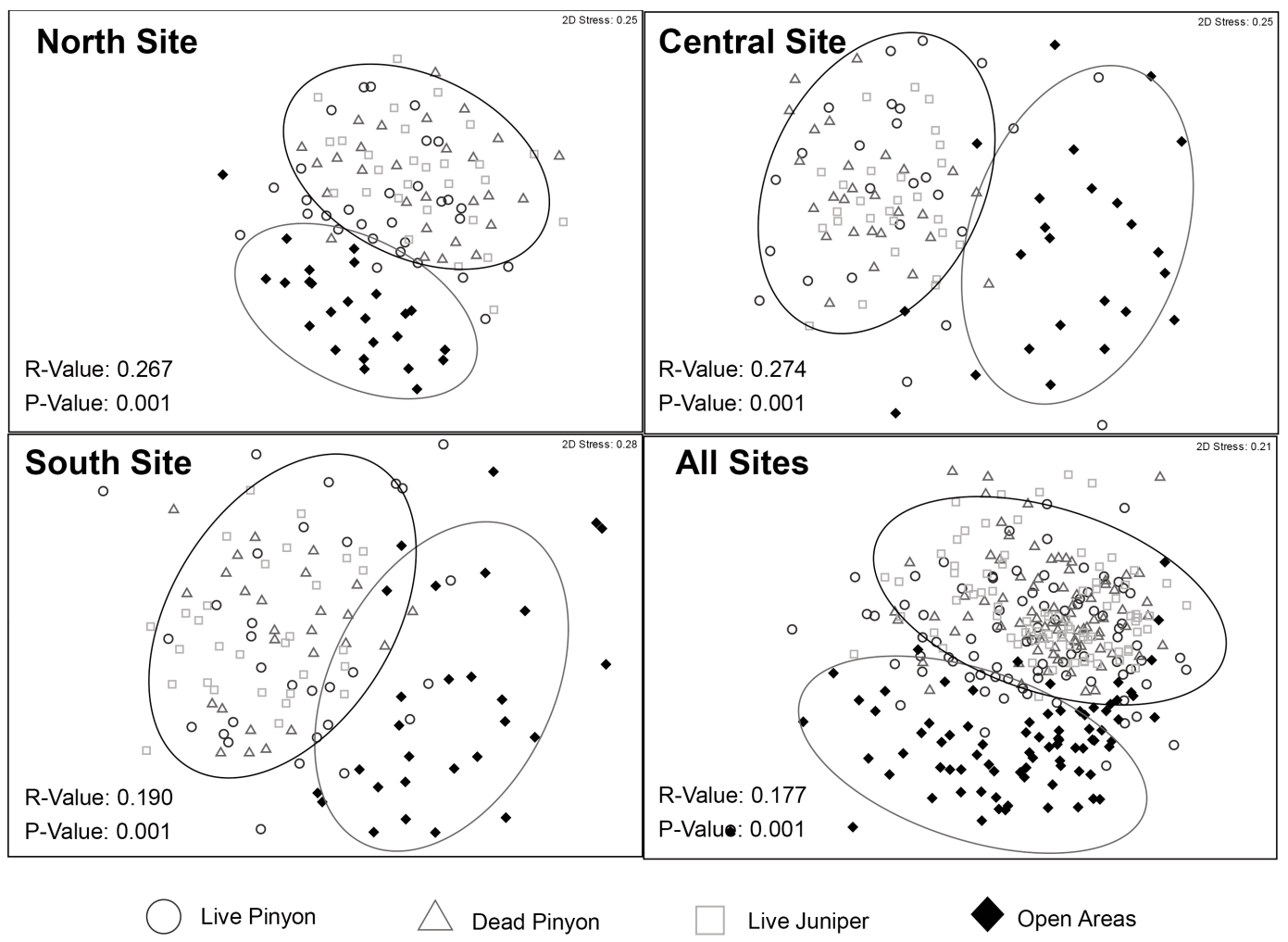

Fig. 5. Scatter plot showing arthropod community differences between microhabitat characteristics in each region. Upward facing triangles represent the arthropod community under live pinyons; downward facing triangles represent the arthropod community under dead pinyons; open squares represent the arthropod community under live junipers; and solid black diamonds represent the arthropod community in open areas. The large circles around the clustered groups are only to aid the reader's eye; they encircle the groupings and are not meant to suggest causality. Results from MRPP are given as $R$ and $P$ values.

A total of 14 species were indicators for high-mortality habitats and preferred the habitat under dead pinyons and in open areas, whereas 7 species were indicators for lowmortality habitats and preferred habitat under live pinyons and live junipers. Of those 14 species, 4 were considered strong indicators of high pinyon mortality, and 4 were strong indicators of low mortality (Table 5). A comparison between the arthropod communities from the microhabitat analysis and the ovall mortality analysis suggested that the high-mortality areas most closely resemble the open area plots rather than the other forested plots.

\section{Discussion}

Arthropod Community Responses

Differences in arthropod community composition were largely driven by the differences in habitat complexity between high and low pinyon mortality sites. Based on our microhabitat data, $49 \%$ of the surface-dwelling arthropods were indicator taxa, occurring in specific habitat types indicative of high- or low-mortality habitats. Though the loss of $4 \%$ of canopy cover and an increase in woody biomass may seem minor in the overall landscape, nevertheless, arthropod communities showed strong responses to these changes.

Many studies show that habitat complexity is positively associated with the richness of fauna at a range of spatial scales (Uetz 1979, August 1983, Huston 1994, Catling and Burt 1995, Humphrey et al. 1999, Hansen 2000).

Biotic factors such as tree canopy cover, shrub canopy cover, and ground herb cover form the basis for defining habitat complexity (August 1983), but identifying and quantifying the generality of these factors can be challenging 


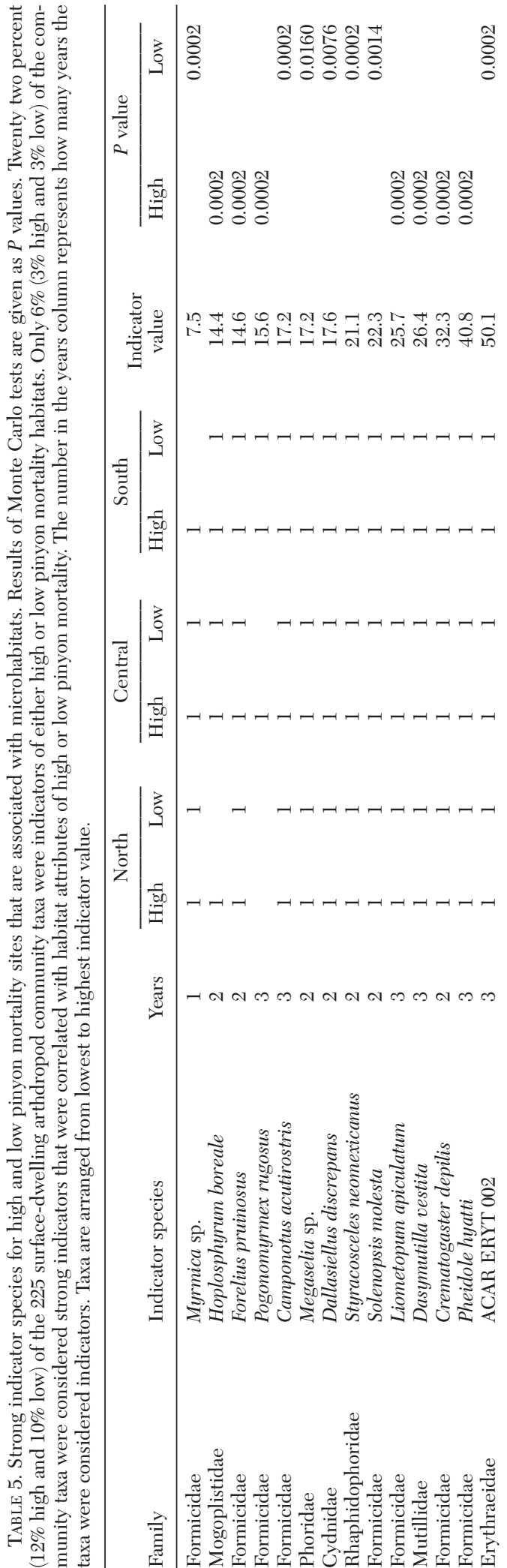

(Lawton 1999). We examined differences in canopy cover and fallen woody debris, which may have been among the many contributors to habitat complexity differences in our study sites. It is unlikely that a single habitat characteristic can control arthropod community structure unless the degree of difference is high, such as in the case of a large tree mortality event leading to an increase in the amount of woody debris. It is unclear if canopy cover and/or the presence of woody debris alone had any effect on arthropod community structure, but it is possible that a suite of habitat characteristics combined may have contributed to the dwelling preferences of arthropods in our study sites (e.g., Gardner et al. 1995, Lassau et al. 2005). Microhabitat preferences of ground-dwelling arthropods are most likely influenced by the arthropods' feeding habits and sources of refuge, and may induce arthropod community responses through predatorprey relationships and foraging success (Bartholomew et al. 2000).

Coarse woody debris has been recognized as important to many wildlife species, especially arthropods (Harmon et al. 1986, Spies et al. 1988, Schiegg 2000, Apigian et al. 2006), and such debris is concomitant with canopy cover, as it influences resource availability on the forest floor (Stephens et al. 2007). However, the role of dead woody debris in an ecosystem is largely dependent on the size, form, and orientation of the wood, as well as the variety of resident flora and fauna (Steed and Wagner 2002). For example, small twigs and branches may only contribute to the complexity of organic decomposition of litter on the ground, whereas larger logs may contribute to refuge habitat and lengthy decomposition rates leading to increased soil moisture, recruitment of fungi, termites, and other organisms. Typically coarse woody debris recruitment is largely dependent on episodic events such as high-severity fires and, to a lesser degree, events during stand development (Stephens et al. 2007). The drought that occured in 2002 created extensive tree mortality leading to the increase in woody biomass on the ground. These effects of drought helped us identify habitats of high complexity, as well as the microhabitat preferences of wildlife. Our results were inconclusive about the habitat preferences of saproxylic arthropods (e.g., some ants in our study), most likely 
because of the sparse amounts of large woody biomass on the ground or the number of pitfall traps directly adjacent to large woody biomass.

\section{Species Responses}

Darkling beetles (Tenebrionidae) and ground beetles (Carabidae) both typically seek shelter under rocks and woody debris (Haila et al. 1994). The larvae of darkling beetles often feed on rotten woody debris, whereas the predaceous ground beetles may feed on the larvae of other beetles. The fact that these groups were most abundant in high pinyon mortality habitats suggests that they may be utilizing the increased amount of woody debris in the high-mortality habitats and thus are indicators of high complexity habitats. Lassau et al. (2005) determined that beetle diversity and compositional differences were strongly associated with habitats of high complexity and that a suite of habitat characteristics not restricted only to woody debris contributes to these compositional differences. Molnár et al. (2001) evaluated ground beetle diversity in relation to forest edge between oak-hornbeam forests and herbaceous grasslands. They found diversity of ground beetles to be significantly higher at the forest edge and noted a strong correlation of leaf litter, canopy cover, and prey abundance with carabid beetle diversity.

However the opposite is true for ants. Lassau and Hochuli (2004) showed that ant species richness was higher in low-complexity habitats and was negatively associated with ground herb cover, tree canopy cover, soil moisture, and leaf litter. Many ant species, specifically harvester ants (Pogonomyrmex spp.), are commonly found in open areas (Crist and Wiens 1994, McIntyre 1999). Harvester ants Pogonomyrmex occidentalis Cresson and Pogonomyrmex rugosus Emery were the 2 most common species of ants collected in our study sites, but they were more abundant in the highmortality habitats. In our study sites, harvester ants may be responding to the increase in openness in high-mortality habitats, and to a lesser degree to the complexity of woody debris on the ground. Other ant species such as acrobat ants (Crematogaster depilis Wheeler) and bigheaded ants (Pheidole hyatti Emery) were also abundant in the high-mortality habitats and have been known to have positive correlations with environmental disturbances (Whitford et al. 1999). Other ant species such as carpenter ants (Camponotus ocreatus Emery and Camponotus vicinus Mayr) are common in forested habitats and typically occupy standing and fallen dead wood. We expected these ants to be more prevalent in our high-mortality habitats with the increase in dead pinyons, yet they were more abundant in our low-mortality sites. Though carpenter ants are referred to as saproxylic arthropods, their dependence on wood is also largely driven by the presence of moisture and dampness of the wood. The lack of canopy cover in our high-mortality sites most likely affects the amount of soil moisture retention in dead trees.

The lack of differences in species richness and abundance between high- and lowmortality environments was likely due to "highmortality specific" and "low-mortality specific" species offsetting each other. This offsetting effect was also noted in Clifford et al. (2008) when indicator taxa for either high- or lowmortality environments were nearly equal in abundance. Although we found strong differences between low- and high-mortality sites in species composition, the microhabitat data indicated that these arthropod responses to mortality may require years to emerge as the litter-dominated ground cover underneath dead trees is replaced by grass/herb cover.

\section{Habitat Change}

Arthropod communities were different between low- and high-mortality sites, and the community compositions were strongly correlated with intrinsic differences in canopy cover that may have existed prior to the drought in 2002-2003. However, differences in fallen woody debris, as a result of the drought, most likely contributed to differences in arthropod community dynamics. Jabin et al. (2004) noted that sites with increased coarse woody debris yielded higher numbers of arthropod taxa than sites with less woody debris, and this abundance varied for specific groups of arthropods responding to seasonal differences.

The intense drought in 2002, with consequent pinyon pine mortality, caused dramatic landscape changes by reducing canopy cover and increasing woody debris (Breshears et al. 2005, Shaw et al. 2005). However, it may take a considerable amount of time for the communities of ground-dwelling arthropods to fully respond to the increase in habitat complexity. Most ground-dwelling arthropods 
seek shelter beneath large woody debris that touches the soil and has had time to decay (Varady-Szabo et al. 2006). Many of the trees that died were still standing when pitfall traps were deployed in August 2005. By 2007 many of the dead trees and fallen branches had been in decay at least 5 years or more. However, dead trees usually do not fall to the ground until 10 years after death (Kearns et al. 2005), which means the peak of the arthropod response may not occur until 2013-2019.

Decomposition rates of woody debris often increase during rainy seasons due to an increase in soil moisture and humidity, which allows fungi and other microorganisms to thrive. A combination of increased precipitation and fallen woody debris may explain why arthropod abundance was higher in high-mortality habitats in 2007. We documented a significant $(P<0.001)$ increase in precipitation in 2006 , which may have resulted in increased habitat complexity in vegetation combined with increased decay of large amounts of woody debris. Our results are consistent with Lockaby et al. (2002), who reported that arthropods responded to increased complexity and decay of woody debris. Temporal variation during these weather events often drives "seasonality" of food resources for specific arthropods, and it is unclear whether the differences we observed were driven by precipitation, because we only sampled arthropods during the monsoon season. Also, there may have been an increase in fallen woody debris in the high-mortality habitats from 2005 to 2007, thus increasing the amount of habitat complexity and refugia for ground-dwelling arthropods.

Significantly higher grass cover in the highmortality sites could account for the significant differences in herbivore abundance between high- and low-mortality sites. Many of the herbivores found were seed bugs and leafhoppers, which may have been feeding on the blue grama (B. gracilis), which was more abundant in high-mortality habitats. Predator abundance often parallels herbivore abundance due to the increase in prey availability (Hassell 1978). However, overall differences in predator abundance were not significant $(P=0.202)$. There were 2 major predator groups found in opposite habitat types: arachnids (spiders and mites) were more abundant in low pinyon mortality habitats, wheras predaceous ground beetles (Carabidae) were more abundant in high-mortality habitats; thus, the 2 groups offset each other, thereby explaining the lack of difference in predator abundance between habitat types.

The open areas in the high-mortality habitats were analogous to the vegetation characteristics of grasslands that often border pinyon-juniper woodlands. Lightfoot et al. (2008) documented arthropod communities as unique among different habitats, which include grasslands (having open canopies) and pinyon-juniper woodlands (having canopy cover). An additional study documented canopy cover as one of the most important factors influencing carabid beetle diversity in oakhornbeam forests that border herbaceous grasslands (Molnár et al. 2001). Lassau et al. (2005) also noted that the high numbers of singletons in low-complexity habitats might result from transient individuals passing through to get to habitats of high complexity. In our study sites, intrinsic differences between canopy cover were noted, and canopy loss from dead pinyons only increased the amount of openness already present in our sites. Thus ground-dwelling arthropod communities in high-mortality habitats were similar to the grassland arthropod communities as a result of drought.

Arthropod community composition did show annual and regional differences; however, the differences were not consistent and varied from year to year. Despite the large-scale mortality of pinyon pine in the MRGB, canopy understory and habitat complexity from fallen trees only accounted for $4 \%$ of the change in habitat structure for high-mortality habitats, yet community composition of ground-dwelling arthropods was still different between highand low-mortality sites for all 3 years (20052007) and in all 3 regions (north, central, and south). We suggest this result stemmed from the intrinsic differences in canopy cover that existed prior to the 2002-2003 drought.

\section{Conclusion}

Overall canopy loss was $2 \%$ for low pinyon mortality sites and 6\% for high pinyon mortality sites. Arthropod composition differences between low- and high-mortality areas were driven by an absolute difference of $4 \%$ in canopy cover and an increase in woody ground cover. A more drought-tolerant species of grass, B. gracilis, was observed at all high-mortality sites, and its presence may have been due to 
intrinsic differences in canopy cover. While overall arthropod species richness and abundance was not significantly different between mortality sites until $2007,22 \%$ of the surfacedwelling arthropods were indicator species that responded to pinyon mortality, either positively or negatively, showing that several arthropod abundances did change. Also $49 \%$ of the surface-dwelling arthropods were habitat specialists, specifically in open intercanopy areas, which were indicative of high-mortality sites based on canopy cover. Arthropod community composition in open areas resembled the arthropod community of high-mortality sites. It is possible that differences in richness and abundance of arthropods may have been due to intrinsic differences in canopy cover that existed prior to the 2002-2003 drought. However, amount of fallen woody debris was the only difference that was directly associated with drought-induced mortality of pinyons and could also account for arthropod community differences between sites. It is clear that there have been many ecological impacts of drought-induced mortality on pinyon-juniper woodlands from the stand level to the landscape level (e.g., Royer et al. 2011, Hicke et al. 2012), showing the importance of using arthropods to monitor rapid climatically-driven vegetation shifts that are projected to increase in the future (Williams et al. 2012).

\section{ACKNOWLEDGMENTS}

This research was supported by the USDA Forest Service Rocky Mountain Research Station Middle Rio Grande Ecosystem Management Unit and the National Science Foundation under Grant No. DEB-0443526. We thank Gabriel Lung, Jackie Dorland, Edwin Delph, John-Paul Hodnett, and Jacob Higgins for their assistance in fieldwork and data entry. We acknowledge Jessica Delph for her assistance in plant identifications and field work.

\section{Literature Cited}

Apigian, K., D. Dahlsten, and S.L. Stephens. 2006. Fire and fire surrogate treatment effects on leaf arthropods in a western Sierra Nevada mixed-conifer forest. Forest Ecology Management 222:110-122.

August, P.V. 1983. The role of habitat complexity and heterogeneity in structuring tropical mammal communities. Ecology 64:1495-1507.

Bartholomew, A., R.J. Diax, and G. Cicchetti. 2000. New dimensionless indices of structural habitat complexity: predicted and actual effects on a predator's foraging success. Marine Ecology Progress Series 206:45-58.

BEALS, E.W. 1984. Bray-Curtis ordination: an effective strategy for analysis of multivariate ecological data. Advances in Ecological Research 14:1-55.

Breshears, D.D., N.S. Cobb, P.M. Rich, K.P. Price, C.D. Allen, R.G. Balice, W.H. Romme, J.H. Kastens, M.L. Floyd, J. Belnap, ET AL. 2005. Regional vegetation die-off in response to global-change-type drought. Environmental Science 102:15144-15148.

Brown, J.H., T.G. Whitham, S.K. Morgan-Ernest, and C.A. Gehring. 2001. Complex species interactions and the dynamics of ecological systems: long-term experiments. Science 293:643-650.

BRown, J.K. 1974. Handbook for inventorying downed woody material. GTR-INT-16, USDA Forest Service, Ogden, UT.

Catling, P.C., And R.J. Burt. 1995. Studies of the grounddwelling mammals of eucalypt forests in south-eastern New South Wales: the effect of environmental variables on distribution and abundance. Wildlife Research 22:669-685.

CLARKE, K.R. 1993. Non-parametric multivariate analyses of changes in community structure. Australian Journal of Ecology 18:117-143.

Clarke, K.R., and R.N. Gorley. 2006. PRIMER v6: user manual/tutorial. PRIMER-E, Plymouth, U.K.

Clifford, M.J., R.J. Delph, N.S. CobB, M.E. Rocca, and P.L. FORD. 2008. Drought induced tree mortality and ensuing bark beetle outbreaks in Southwestern pinyon-juniper woodlands. USDA Forest Service Proceedings RMRS 39-51.

Clifford, M.J., P.D. Royer, N.S. CobB, D.D. Breshears, AND P.L. FORD. 2013. Precipitation thresholds and drought-induced tree die-off: insights from patterns of Pinus edulis mortality along an environmental stress gradient. New Phytologist 200:413-421, http://dx.doi.org/10.1111/nph.12362

Cobb, N.S., S. Mopper, C.A. Gehring, M. Caouette, K.M. Christensen, and T.G. Whitham. 1997. Increased moth herbivory associated with environmental stress of pinyon pine at local and regional levels. Oecologia 109:389-397.

Crist, T.O., AND J.A. Wiens. 1994. Scale effects of vegetation on forager movement and seed harvesting by ants. Oikos 69:37-46.

DALY, C. 2002. Variable influence of terrain on precipitation patterns: delineation and use of effective terrain height in PRISM [online]. Available from: http://www .Ocs.Orst.edu/prism/effter.pdf

Dennis, P., M.R. Young, C.L. Howard, and I.J. Gordon. 1997. The response of epigeal beetles (Coleoptera: Carabidae, Staphylinidae) to varied grazing regimes on upland Nardus stricta grasslands. Journal of Applied Ecology 34:433-443.

Ellis, L.M., C.S. Crawford, and M.C. Molles Jr. 2001. Influence of annual flooding on terrestrial arthropod assemblages of Rio Grande riparian forest. Regulated Rivers: Research and Management $17: 1-20$.

Evans, R.A. 1988. Management of pinyon-juniper woodlands. General Technical Report INT-249, USDA Forest Service, Intermountain Research Station, Ogden, UT.

Floyd, M.L., M.J. Clifford, N.S. Cobb, D. Hanna, R.J. Delph, P. Ford, and D. Turner. 2009. Relationship 
of stand characteristics to drought-induced mortality in piñon-juniper woodlands in Colorado, Arizona and New Mexico. Ecological Applications 19: 1223-1230.

Gardner, S.M., M.R. Cabido, G.R. Valladeres, and S. Diaz. 1995. The influence of habitat structure on arthropod diversity in Argentine semi-arid Chaco forest. Journal of Vegetation Science 6:349-356.

GonZÁlez-Megías, A., J.M. Gómez, and F. SÁnchezPiÑERO. 2004. Effects of ungulates on epigeal arthropods in Sierra Nevada National Park (southeast Spain). Biodiversity and Conservation 13:733-752.

Grieg-Smith, P. 1983. Quantitative plant ecology. 3rd edition. Blackwell Scientific Publications, London, United Kingdom.

Haila, Y., I.K. Hanski, J. Niemelae, P. Punttila, S. RaIVIO, AND H. Tukia. 1994. Forestry and the boreal fauna: matching management with natural forest dynamics. Annales Zoologici Fennici 31:187-202.

Hansen, R.A. 2000. Effects of habitat complexity and composition on a diverse litter microarthropod assemblage. Ecology 81:1120-1132.

Harmon, M.E., J.F. Franklin, FJ. Swanson, P. Sollins, S.V. Gregory, J.D. Lattin, H.H. Anderson, S.P. Cline, N.G. Aumen, J.R. SEDELL, ET AL. 1986. Ecology of coarse woody debris in temperate ecosystems. Pages 133-302 in A. MacFaden and E.E. Fored, editors, Advances in Ecological Research 15. Academic Press, New York, NY.

Hassell, M.P. 1978. The dynamics of arthropod predatorprey systems. Monographs in Population Biology 13: 204-214.

Hicke, J.A., C.D. Allen, A.R. Desai, M.C. Dietze, R.J. Hall, E.H. Hogg, D.M. Kashian, D. Moore, K.F. RafFa, R.N. Sturrock, and J. Vogelsmann. 2012. Effects of biotic disturbances on forest carbon cycling in the United States and Canada. Global Change Biology 18:7-34.

Higgins, J.W., N.S. Cobb, S. Sommer, R.J. Delph, and S.L. Brantley. 2014. Ground-dwelling arthropod responses to succession in a pinyon-juniper woodland. Ecosphere 5:1-29.

Humphrey, J.W., C. Hawes, A.J. Pearce, R. Ferris-Khan, AND M.R. JukEs. 1999. Relationships between insect diversity and habitat complexity in plantation forests. Forest Ecology and Management 113:11-21.

Huston, M.A. 1994. Hidden treatments in ecological experiments: re-evaluating the ecosystem function of biodiversity. Oecologia 110:449-460.

Intachat, J., J.D. Holloway, and M.R. Speight. 1997. The effects of different forest management practices on geometroid moth populations and their diversity in peninsular Malaysia. Journal of Tropical Forest Science 9:411-430.

[ITT] Interagency Technical Team. 1996. Sampling vegetation attributes, interagency technical reference. Report No. BLM/RS/ST-96/002+1730, USDI Bureau of Land Management, Natural Applied Resources Science Center, Denver, CO.

Jabin, M., D. Mohr, H. Kappes, And W. Topp. 2004. Influence of deadwood on density of soil macro-arthropods in a managed oak-beach forest. Forest Ecology and Management 194:61-69.

Kearns, H., W. Jacobi, and D. Johnson. 2005. Persistence of pinyon pine snags and logs in southwestern Colorado. Western Journal of Applied Forestry 20: 247-252.
Kershaw, K.A. 1973. Quantitative and dynamic plant ecology. 2nd edition. New York, NY.

Kleinman, S.J., T.E. DeGomez, G.B. Snider, and K.E. WiLliams. 2012. Large-scale pinyon ips (Ips confusus) outbreak in southwestern United States tied with elevation and land cover. Journal of Forestry 110:194-200.

Larocque, I., R. Hall, and E. Grahn. 2001. Chironomids as indicators of climate change: a 100-lake training set from a subarctic region of northern Sweden (Lapland). Journal of Paleolimnology 26: 307-322.

Lassau, S.A., AND D.R. Hochuli. 2004. Effects of habitat complexity on ant assemblages. Ecography 27: 157-164.

Lassau, S.A., D.R. Hochuli, G. Cassis, and A.M. Reid. 2005. Effects of habitat complexity on forest diversity: do functional groups respond consistently? Diversity and Distributions 11:73-82.

LAWTON, J.H. 1999. Are there general laws in ecology? Oikos 84:177-194.

Lightfoot, D.C., S.L. Brantley, and C.D. Allen. 2008. Geographic patterns of ground-dwelling arthropods across an ecoregional transition in the North American Southwest. Western North American Naturalist 68:83-102.

Lockaby, B.G., B.D. Keeland, J.A. Stanturf, M.D. Rice, G. Hodges, And R.M. Governo. 2002. Arthropods in decomposing wood of the Atchafalaya River basin. Southwestern Naturalist 4:339-352.

Logan, J.A., J. Regniere, And J.A. Powell. 2003. Assessing the impacts of global warming on forest pest dynamics. Frontiers in Ecology and the Environment 1:130-137.

McCune, B., And E.W. Beals. 1993. History of the development of Bray-Curtis ordination. Pages 67-79 in J.S. Fralish, R.P. McIntosh, and O.L. Loucks, editors, John T. Curtis: fifty years of Wisconsin plant ecology. Wisconsin Academy of Sciences, Arts and Letters, Madison, WI

McCune, B., And J.B. Grace. 2002. Analysis of ecological communities. MjM Software Design, Gleneden Beach, OR.

McCune, B., And M.J. MefFord. 2006. PC-ORD. Multivariate analysis of ecological data, version 5.10. MjM Software, Gleneden Beach, OR.

McIntyre N.E. 1999. Use of Pogonomyrmex occidentalis (Hymenoptera: Formicidae) nest-sites by tenebrionid beetles (Coleoptera: Tenebrionidae) for oviposition and thermoregulation in a temperate grassland. Southwestern Naturalist 44:379-382.

Molnár, T., T. Magura, B. Tóthmérész, and Z. Elek. 2001. Ground beetles (Carabidae) and edge effect in oak-hornbeam forest and grassland transects. European Journal of Soil Biology 37:297-300.

Morrison, M.L., AND B.G. MarCot. 1995. An evaluation of source inventory and monitoring programs used in national forest planning. Environmental Management 19:147-156.

Parmenter, R.R., C.A. Parmenter, and C.D. Cheney. 1989. Factors influencing microhabitat partitioning among coexisting species of arid-land darkling beetles (Tenebrionidae): behavioral responses to vegetation architecture. Southwestern Naturalist 34:319-329.

Royer, P.D., N.S. Cobb, M.J. Clifford, C.-Y. Huang, D.D. Breshears, H.D. Adams, and J.C. Villegas. 2011. Extreme climatic event-triggered overstorey 
vegetation loss increases understorey solar input regionally: primary and secondary ecological implications. Journal of Ecology 99:714-723.

SchiEgG, K. 2000. Are there saproxylic beetle species characteristic of high dead wood connectivity? Ecography 23:579-587.

ShaW, J.D., B.E. SteED, AND L.T. DeBlander. 2005. Forest inventory and analysis (FIA) annual inventory answers the question: what is happening to pinyonjuniper woodlands? Journal of Forestry 103:280-285.

Spies, T.A., J.F. Franklin, and T.B. Thomas. 1988. Coarse woody debris in Douglas-fir forests of western Oregon and Washington. Ecology 69:1689-1702.

SPSS. 2007. SPSS for Windows, version 16.0. SPSS, Inc., Chicago, IL.

Steed, B.E., And M.R. Wagner. 2002. Overview of agents and patterns of mortality and resulting coarse woody debris recruitment in western forests. Pages 407-433 in W.F. Laudenslayer, P.J. Shea, B.E. Valentine, C.P. Weatherspoon, and T.E. Lisle, technical coordinators, Proceedings of the Symposium on the Ecology and Management of Dead Wood in Western Forests. General Technical Report PSW-GTR-181, USDA Forest Service.

Stephens, S.L., D.L. Fri, E. Franco-Vizcaino, B.M. ColLins, AND J.M. Moghaddas. 2007. Coarse woody debris and canopy cover in an old-growth Jeffrey pine-mixed conifer forest from the Sierra San Pedro Martir, Mexico. Forest Ecology and Management 240:87-95.

Trotter, T.A., III, N.S. CobB, and T.G. Whitham. 2008. Arthropod community diversity and trophic struc- ture: a comparison between extremes of plant stress. Ecological Entomology 33:1-11.

UetZ, G.W. 1979. The influence of variation in litter habitat on spider communities. Oecologia 40:29-42.

Ugland, K.I., J.S. Gray, and K.E. Ellingsen. 2003. The species-accumulation curve and estimation of species richness. Journal of Animal Ecology 72:888-897.

[USGS] United States Geological Survey. 2004. Climatic fluctuations, drought, and flow in the Colorado River Basin. USGS Fact Sheet 2004-3062, version 2, United States Department of the Interior.

Varady-SZABO, H., AND C.M. Buddle. 2006. On the relationships between ground-dwelling spider (Araneae) assemblages and dead wood in a northern sugar maple forest. Biodiversity and Conservation 15: 4119-4141.

Whitford, W.G., J. Van Zee, M.S. Nash, W.E. Smith, AND J.E. HERRICK. 1999. Ants as indicators of exposure to environmental stressors in North American desert grasslands. Environmental Monitoring and Assessment 54:143-171.

Williams, A.P., C.D. Allen, A.K. Macalady, D. Griffin, C.A. Woodhouse, D.M. Meko, T.W. Swetnam, S.A. Rauscher, R. Seager, H.D. Grissino-Mayer, et al. 2012. Temperature as a potent driver of regional forest drought stress and tree mortality. Nature Climate Change, http://dx.doi.org/10.1038/NCLIMATE1693

Received 14 January 2013 Accepted 19 May 2014

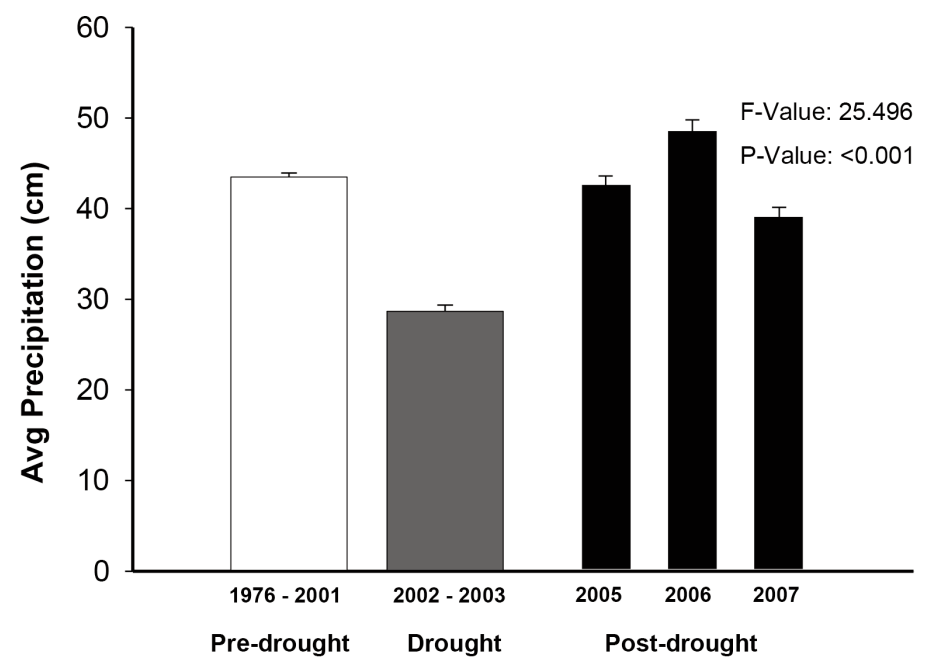

APPEndix 1. Average precipitation (cm) in the Middle Rio Grande Basin (MRGB) for 3 time periods (bars) from 1978 to 2007. Average precipitation during pre-drought (1976-2001) conditions significantly $(P<0.001)$ dropped $34 \%$ during the drought (2002-2003) then increased 35\% during post-drought (2005-2007) conditions. Average precipitation was significantly $(P<0.001)$ higher in 2006 than in 2005 and 2007 . The reduced precipitation and concomitant pinyon mortality support with the conclusion that drought-induced tree mortality occurred in the MRGB as it did regionally (Breshears et al. 2005). The resumption of normal precipitation in 2004 suggests that differences in arthropod communities between high- and low-mortality sites were primarily due to tree mortality and not to direct effects of drought on arthropods. 

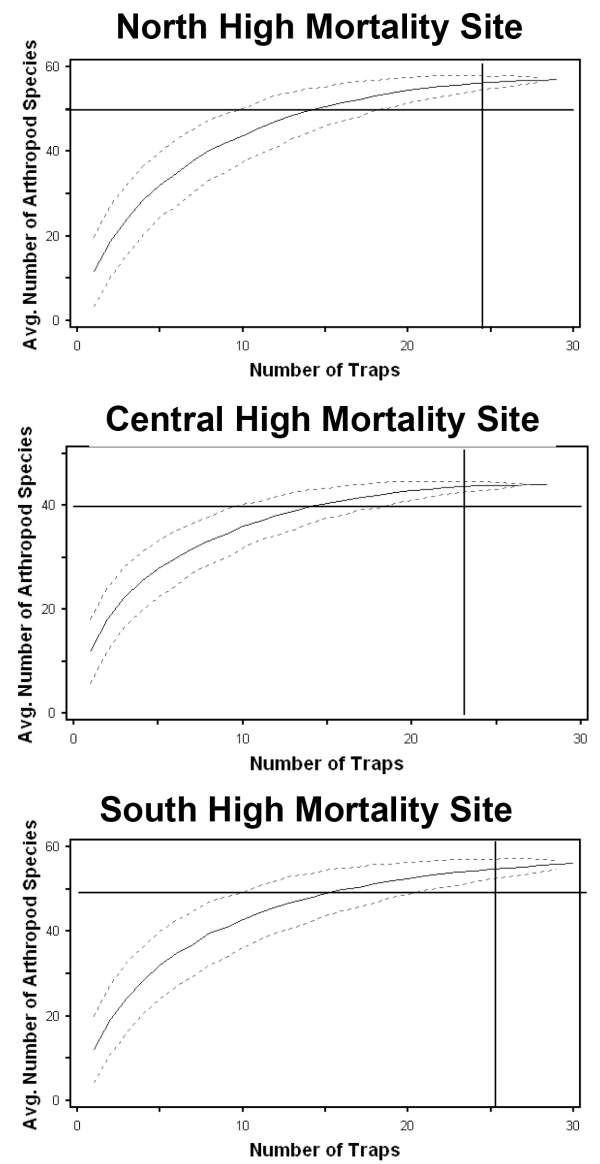
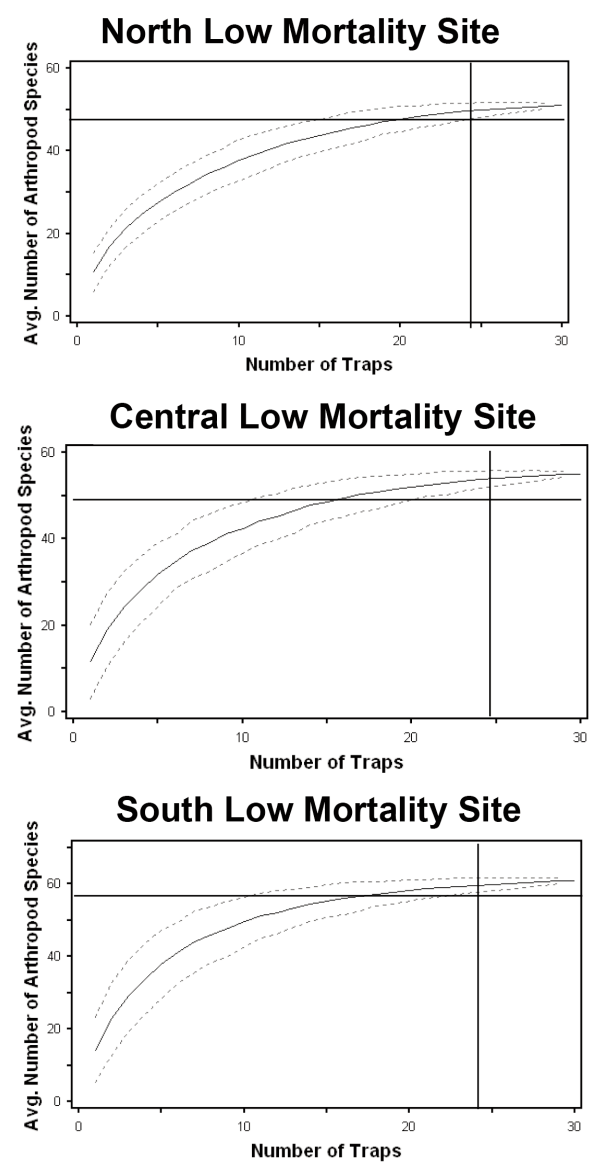

APPENDIX 2. One major concern with any arthropod community-related studies is whether a sufficient sample of the community has been obtained. On the basis of our species accumulation analysis, we determined that 25 traps were sufficient to collect a satisfactory sample of the surface community at each site. We used 32 traps at each site, a number more than sufficient for our study. 


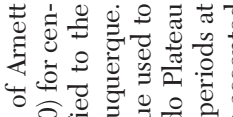

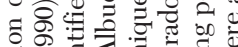

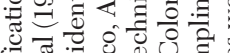

ज讨

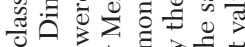

Ð

or

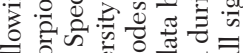

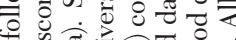

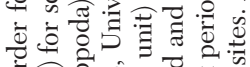

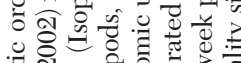

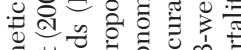

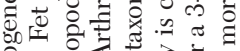

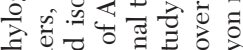

की

$\exists$ के

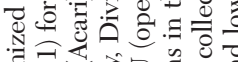

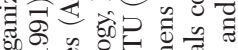

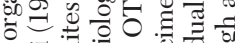

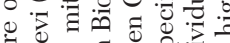

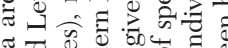

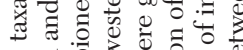

ธ

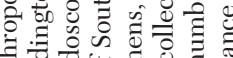

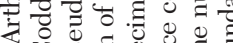

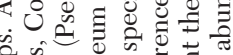

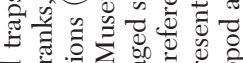

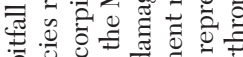

a.

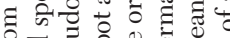

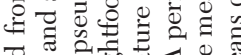

ఫ

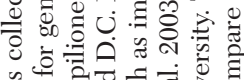

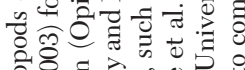

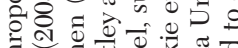

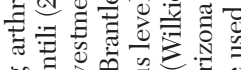

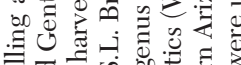

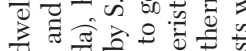

i

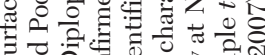

ติ

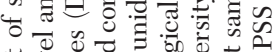

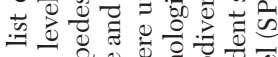

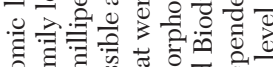

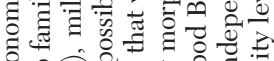

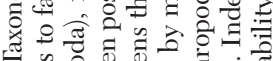

㻤

m

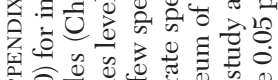

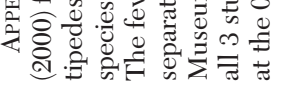

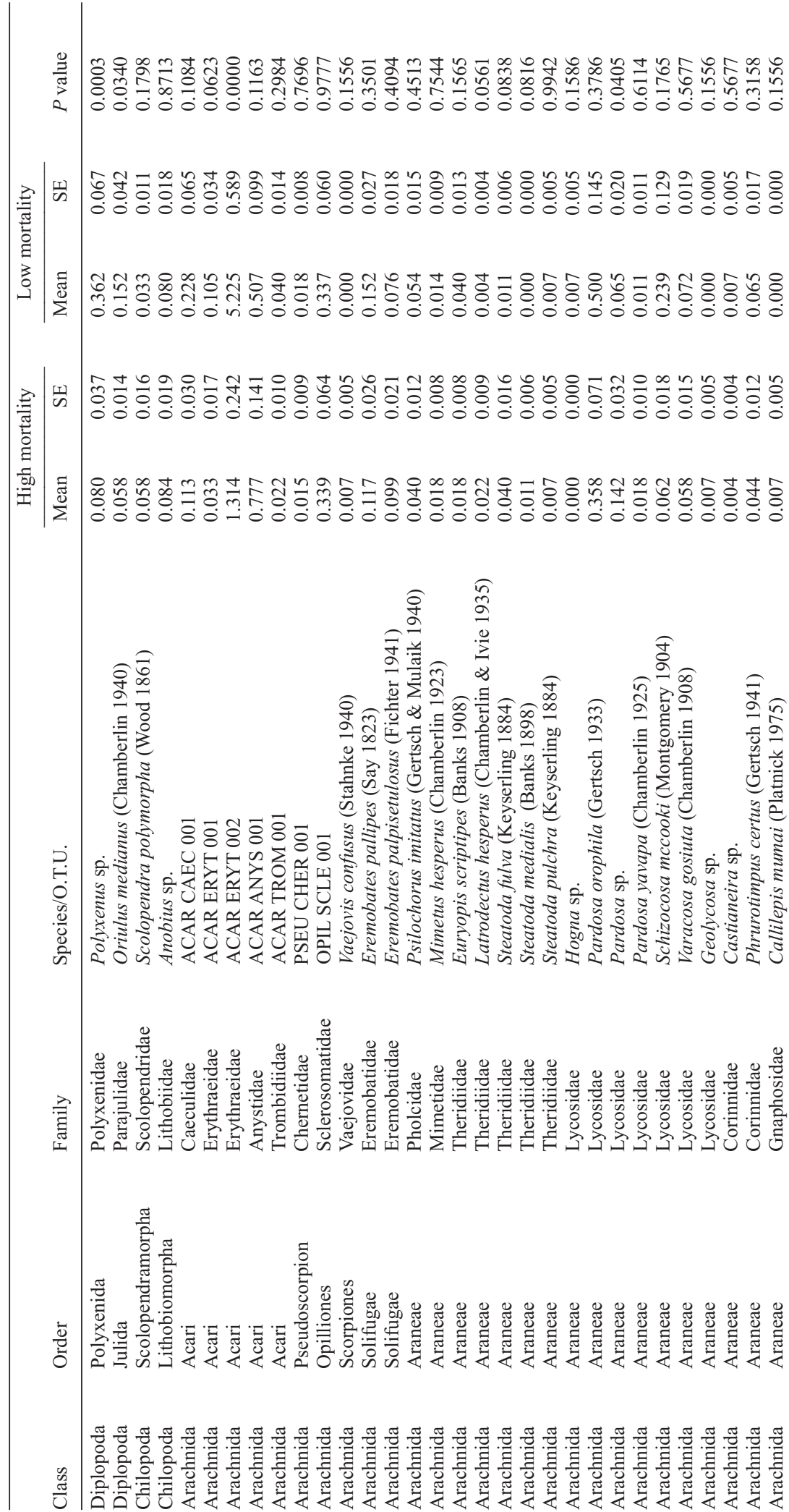




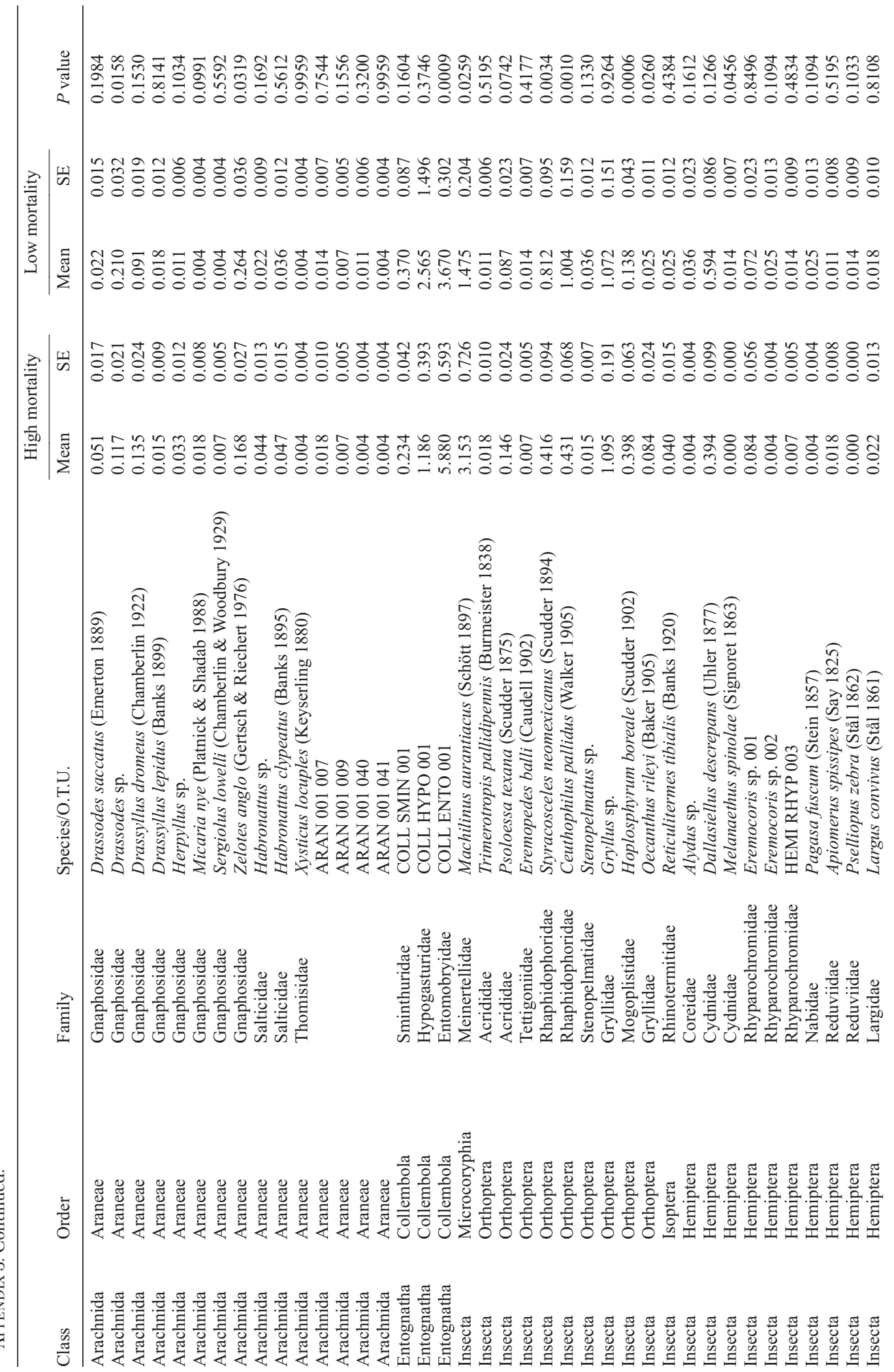




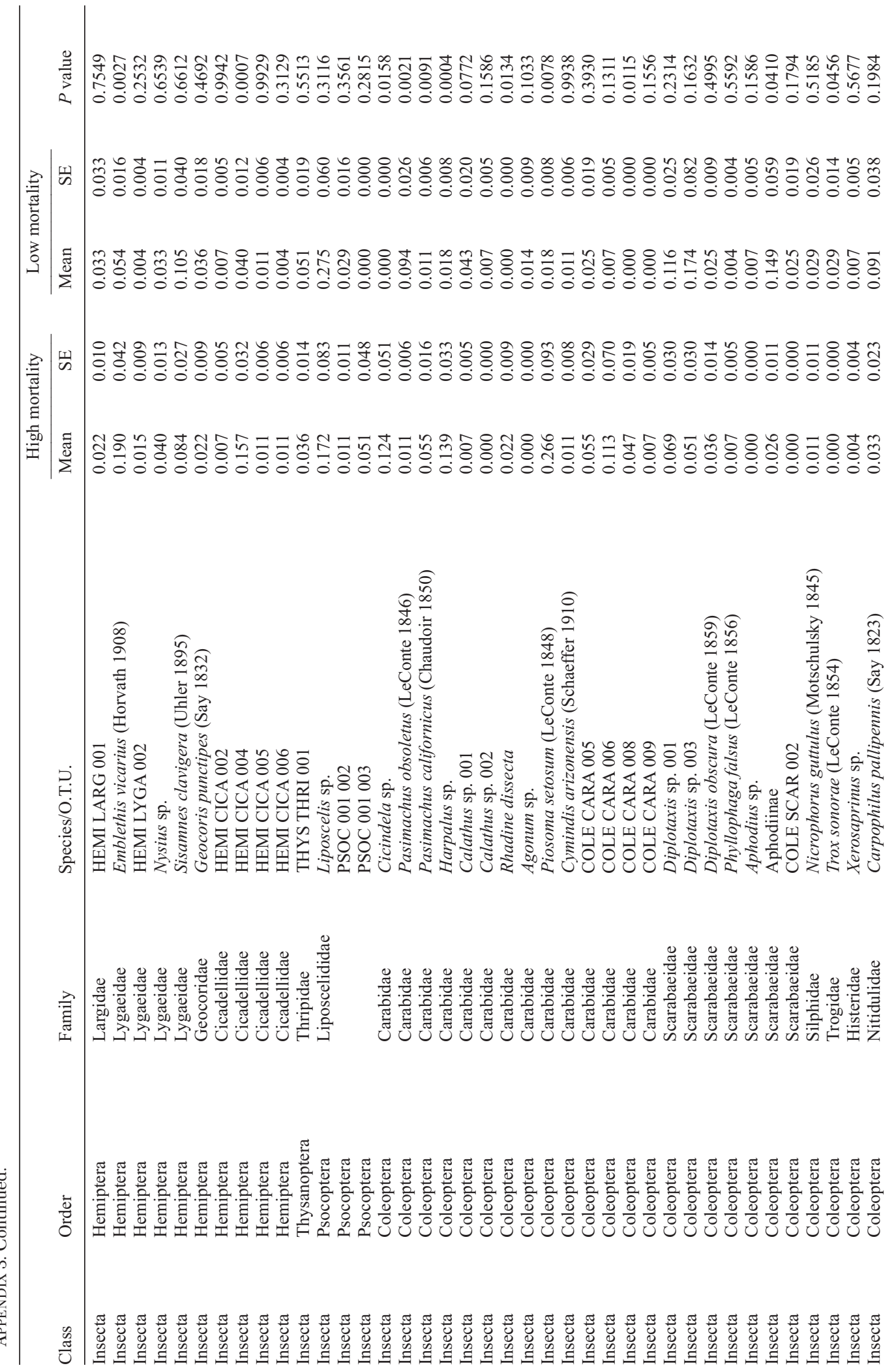




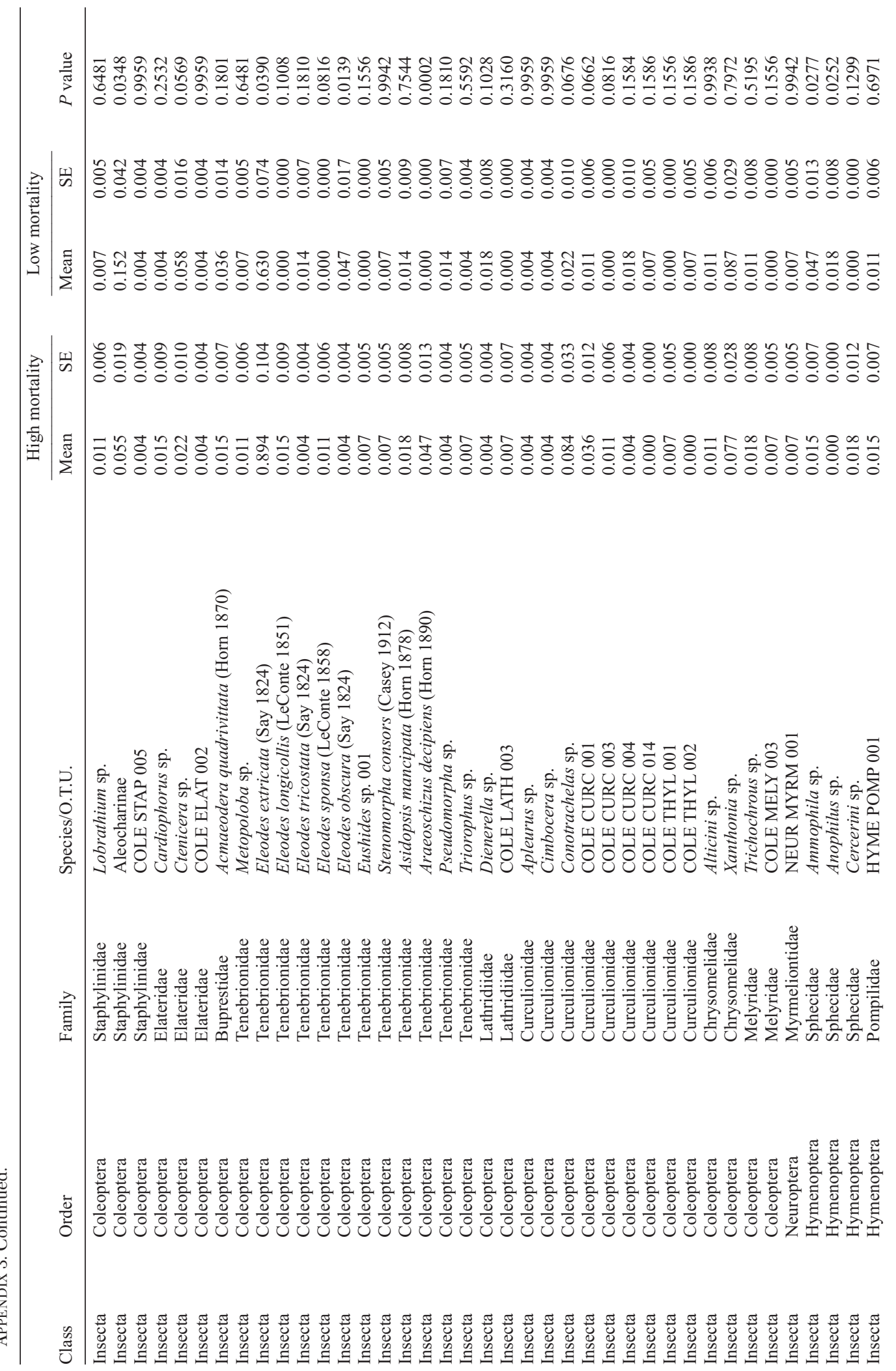




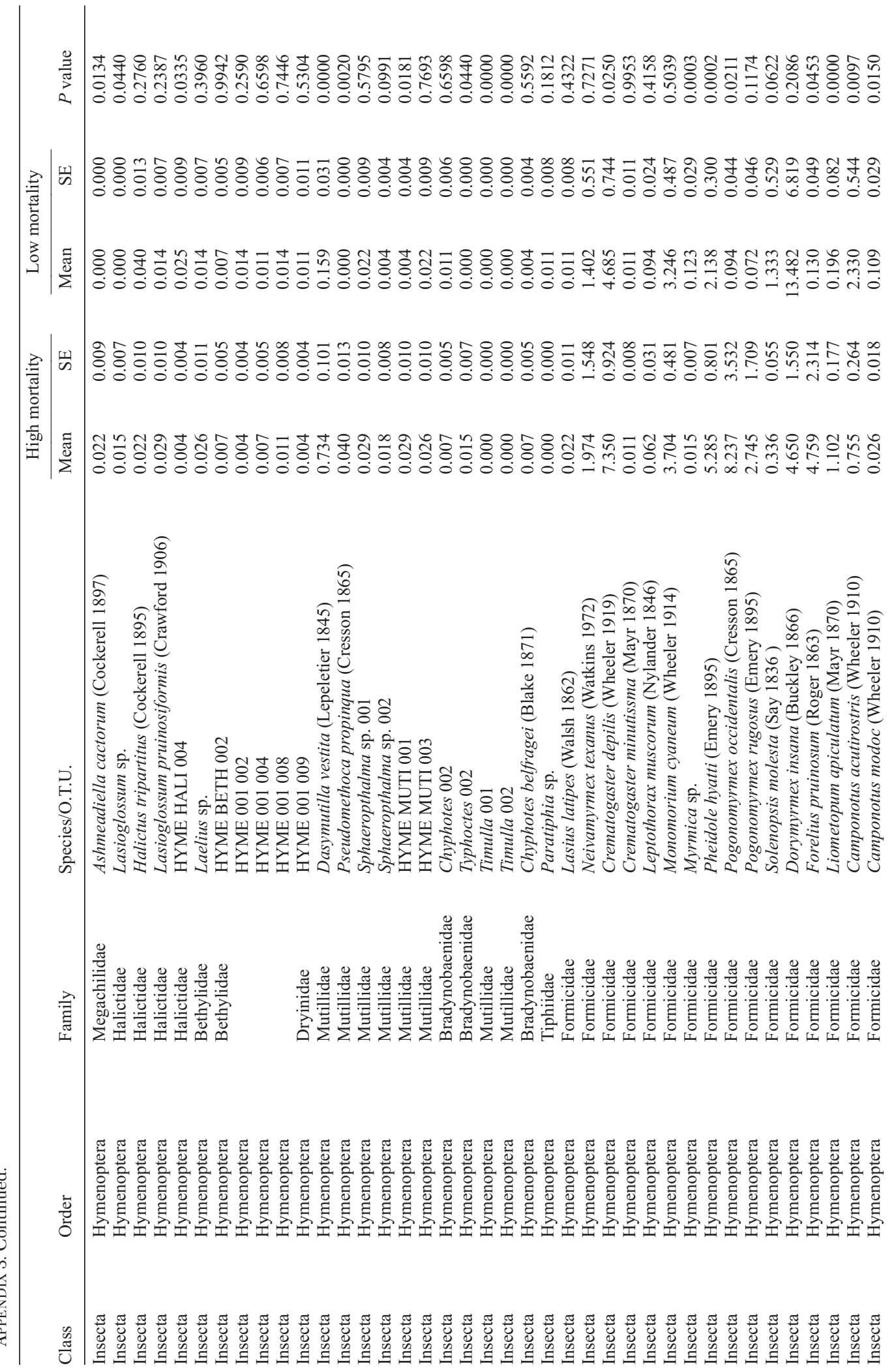




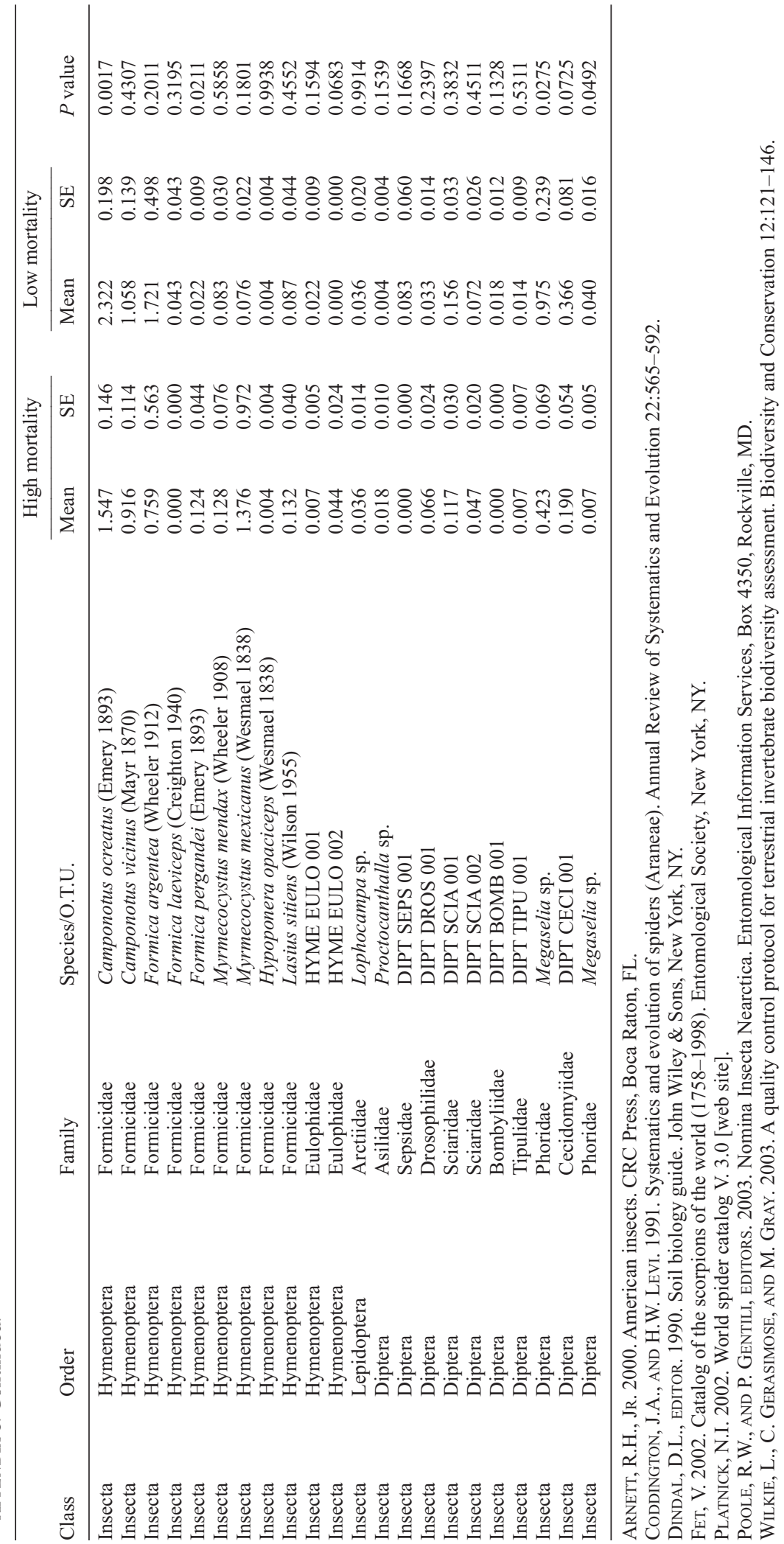

